\title{
ELECTIONS, LEGITIMACY, AND DEMOCRATIC CONSOLIDATION IN SOUTHERN AFRICA Lessons from Zambia, Zimbabwe and Malawi
}

\section{Hangala Siachiwena and Chris Saunders}

Hangala Siachiwena is a post-doctoral researcher in the Institute for Democracy,

Citizenship and Public Policy in Africa at the University of Cape Town

Chris Saunders is an emeritus professor and researcher in the Institute for

Democracy, Citizenship and Public Policy in Africa at the

University of Cape Town

\begin{abstract}
Regular elections are now the norm across most of sub-Saharan Africa, but repeated elections have not guaranteed the consolidation of democracy. Election legitimacy is crucial for democratisation. When losing political actors and their supporters are not satisfied with the electoral process, there is potential for growing political tensions. Fraudulent or controversial elections fail to confer legitimacy on the winners, and undermine the integrity of elections and democracy. Drawing on Afrobarometer data and media accounts, this paper focuses on the most recent elections held in three southern African countries: Zambia, Zimbabwe and Malawi. We show that when citizens believe that elections were not free and fair, there is a decline in their satisfaction with democracy and the trust they have in institutions such as electoral commissions and courts of law. The absence of political reforms to address disputed election outcomes increases the likelihood that future elections will not be contested fairly. This sets countries on a path of democratic decline rather than consolidation.
\end{abstract}

Keywords: elections, legitimacy, democratic consolidation, Malawi, Zambia, Zimbabwe, southern Africa.

\section{INTRODUCTION}

That governments should be elected by citizens at regular intervals is a key democratic principle. While competitive multi-party elections may give governments legitimacy, they are often imperfect and their legitimising effect is 
uneven. Those who support a winning party may accept the outcome as legitimate, while supporters of a losing party may not. In this paper we consider a number of recent cases in southern Africa in which there was contestation over whether an election was free and fair. We explore what happened in the aftermath of the election, for the legitimacy of an election is not decided on polling day itself but is derived from a process that includes the election campaign, the election itself and the aftermath. Do those who lose at the polling booth reject the system or become reconciled to the outcome, hoping to do better in the next election? If the latter, does this mean that at least to some extent, they accept the legitimacy of the process?

In a number of African countries, flawed elections have led to violent clashes between supporters of the winning party and opponents, threatening the very future of the democracy in that country. After a disputed election in Tanzania in October 2020, the leader of the losing opposition party fled the country. Elsewhere, in South Africa for example, those who supported the losing side in an election have come to accept the outcome. In yet other African countries, such as Guinea in 2020, authoritarian leaders have stage-managed elections and used repression to stay in power. We cannot here survey the entire recent history of elections in southern Africa to show how those who lost at the ballot box have responded to the outcome, but will examine a few cases, drawn from Anglophone countries in the region, to see if lessons can be drawn from them. While we are not the first to attempt to survey the legitimacy of African elections and to explore how citizens hold their governments accountable through elections (see for example, Moehler 2013; Lockwood \& Krönke 2020; Wahman 2014), we draw on survey data and media reports and believe we can offer new insights.

Though most countries in the southern African region - which we define as the southern half of the continent, minus the Democratic Republic of Congo - have held national elections in the last five years, their electoral systems vary greatly, and so too the legitimacy of their elections. Much of the southern African region remained under colonial or minority rule until the last quarter of the twentieth century, and liberation wars were fought before independence was achieved. The liberation movements that emerged triumphant when those wars ended remain in power in over half of the countries of the region. Though repeated elections have taken place, this has often not meant any consolidation of democracy. This requires that the outcome of elections be acceptable to both winners and losers, and that elections result in transfers of power between incumbent and opposition (Moehler \& Lindberg 2009). In southern Africa only three countries have seen such transfers of power since independence (or, in the case of South Africa, the transfer of power from the white minority to the black majority in 1994): they are Zambia and Malawi, which both emerged from the dissolution of the Central 
African Federation, a British colonial project, in the early 1960s, and the small country of Lesotho, which is totally surrounded by South Africa. In Zimbabwe, as elsewhere in the region, the party that came to power after a liberation struggle has won a series of elections and remains in power. In the anomalous case of Swaziland, now eSwatini, no electoral contestations have taken place in what remains an absolute monarchy.

Several southern African opposition parties have in recent years challenged the outcomes of elections in the courts. With the major exception of Malawi, one of our case-studies, courts have upheld the election results even in the face of flagrant irregularities. International election observers have often endorsed the results of elections, however flawed they have been. Protests from opposition parties and, increasingly, ordinary citizens, have grown and the issue of legitimacy derived from elections has become key to the evolving nature of the democracies in the region.

We focus here on three members of the Southern African Development Community (SADC): Zambia, Zimbabwe and Malawi. Zambia has witnessed two electoral turnovers since democratising in 1991, but the outcomes of the most recent elections have led to fierce contestation, and democracy in Zambia is faltering, if not in decline. Unlike the other two cases, in Zimbabwe a major liberation war took place before independence and the liberation party that emerged victorious from that war has remained in power since independence. Zimbabwe has consistently performed very poorly when judged by most measures of democracy, and elections have been marred by violence and other gross irregularities. There is little more than a pretence of a working multi-party electoral system, and some dispute that there is any significant space for democratic politics. The situation in Malawi, our third case, is quite different, for Malawi is now only the second African country to have had the outcome of a presidential election overturned by a court (the first was Kenya) and the first to witness a transfer of power after the court required a fresh election to be called.

We first discuss theoretical arguments regarding elections and legitimacy and consider the implications of election legitimacy for democratic consolidation, then employ Afrobarometer data to analyse trends in the measurement of election legitimacy. After discussing the legitimacy of the recent elections in the three countries, the paper concludes by returning to the implications of legitimacy for democratic consolidation.

\section{ELECTIONS, LEGITIMACY AND DEMOCRATIC CONSOLIDATION}

Jaimie Bleck and Nicolas van de Walle argue that Africa has witnessed an 'institutionalisation of elections without democratisation' (Bleck \& Van de Walle 
2018, p. 49). In southern Africa, it is only in eSwatini that opposition parties are not legalised. Elsewhere, regular democratic elections have been held since the democratic wave of the 1990s, though because of the civil war Angola held no election between 1992 and 2008. But despite the holding of elections, Freedom House rated only seven countries in sub-Saharan Africa 'free' in 2020, a decline from nine countries in 2015 (Freedom House 2020). ${ }^{1}$ Zambia, Zimbabwe and Malawi are among the countries classified as 'partly free' (ibid.).

It is clear that conducting regular elections does not guarantee democracy. Yet citizens and political actors expect elections to be of acceptable quality. Staffan Lindberg has argued that the quality of democratic elections must be underpinned by at least three core democratic values: participation, competition, and legitimacy (Lindberg 2004). Participation requires that a range of candidates compete in an election. A decent level of competitiveness among the parties is vital to the democratic values of self-government, accountability and the responsiveness of electoral representatives, and it increases the likelihood of alternation in power. We focus here on the third of these values, legitimacy.

Election legitimacy has been defined as the extent to which political actors believe that an entire election process is legitimate and binding (Elklit \& Reynolds 2002). Williamson (2020, p. 6) defined it as the extent to which the outcome of an election gives the winner the right to govern. The legitimacy of an election can be measured in various ways:

- Was it accepted as 'free and fair'?

- Was there widespread politically-motivated violence during the election campaign or on election day?

- Did the losing party accept the outcome?

The confidence that political actors and citizens have in commissions that oversee elections may be crucial. An expectation that the losing party will accept the results of a legitimate election does not suggest that a challenge to the results is somehow invalid (Erlich \& Kerr 2016; Lindberg 2004).

The existing literature on elections and legitimacy has focused on the extent to which elections provide democratic legitimacy to competitive authoritarian regimes (Diamond 2002; Levitsky \& Way 2010; Schedler 2002). Levitsky and Way (2010, p. 306) identified 14 African countries (including Zambia, Zimbabwe and Malawi) that they classified as 'competitive authoritarian regimes'. These countries had democratic institutions on paper, held regular democratic elections, and

1 Freedom House rates people's access to political rights and civil liberties in 210 countries ranging from the right to vote to freedom of expression and equality before the law. In southern Africa, only Botswana, Namibia and South Africa are listed as 'free'. 
had a level of competition that gave opposition parties a theoretical chance of winning; but, in practice, incumbents subverted democracy (Bogaards \& Elischer, 2016, p. 7). In competitive authoritarian regimes, elections are held to convince the public that elected leaders have a democratic mandate to govern, but leaders in such regimes utilise democratic institutions and procedures to win legitimacy as a means to entrench their power (Williamson 2020, p. 4).

Regular elections are a necessary, but far from sufficient condition for democratic consolidation (Bleck \& Van de Walle 2018, p. 31). A democracy is consolidated when it can be assumed to have survived the threat of democratic breakdown, which occurs when election cycles are aborted or replaced by coups or civil wars (Lindberg 2009). If the ultimate measure of legitimacy is that there is no such breakdown, it follows that the extent to which political actors believe that an election was credible is a key factor in democratic consolidation. A focus on election legitimacy challenges the idea that repeated democratic elections, regardless of their quality, provide a set of institutions, rights and processes that gradually promote and consolidate democratisation (Lindberg 2009). This argument has been challenged by, for example, Matthijs Bogaards, for whom alternation in power, helped by such institutional features as term limits, is crucial for democratic consolidation. Democratic elections need to be complemented by institutional reforms that promote democratisation (Bogaards 2013, p. 159).

When elections fail to confer legitimacy on the winners, the likelihood of breakdown is increased, and the sustainability of democracy is undermined. This may result in increased political protests as a way of disapproving the governing regime (Williamson 2020, p. 1). For its part, the regime may resort to more coercive measures to sustain power. We show that there is reason to be concerned about the quality of recent elections in the three countries in the SADC region that we consider. When elections fail to confer legitimacy on the winners, there is an urgent need for political and institutional reforms before the next election cycle. Failure to achieve such reforms will diminish the confidence that political actors and citizens have in the electoral process and is likely to set countries on a path of democratic decline, and perhaps even breakdown, rather than consolidation.

\section{POPULAR ATTITUDES TOWARDS ELECTIONS, DEMOCRACY AND INSTITUTIONS IN SOUTHERN AFRICA}

Afrobarometer surveys provide a resource to measure aspects of democracy and elections. These surveys include citizens' evaluations of the freeness and fairness of elections, their satisfaction with democracy, and their trust in electoral commissions and courts. We use these evaluations as measures of election legitimacy and confidence in institutions that are crucial for conducting and legitimating elections. 
The seventh round of Afrobarometer surveys, conducted between 2016 and 2018, asked respondents: 'on the whole, how would you rate the freeness and fairness of the last national election?' The response categories to this question were: 'not free and fair', 'free and fair with major problems', 'free and fair with minor problems', and 'completely fair'. Of the 16 countries that constitute the SADC region, Round 7 surveys were conducted in 11. In Figure 1, we present the results to the question from across these 11 countries. Rather than reporting all four response categories, we report results by highlighting the proportion of citizens who rated the elections as 'free and fair' (i.e. free and fair with minor problems and completely fair) and those who rated elections to be 'not free and fair' (i.e. not free and fair, and free and fair with major problems). Respondents in Madagascar and Zimbabwe rated the freeness and fairness of elections held in 2013. In six countries - Botswana, Malawi, Mauritius, Mozambique, Namibia and South Africa - the most recent elections held before Round 7 of the Afrobarometer survey were in 2014. At the time of the surveys the most recent elections were in 2015 in Tanzania, 2016 in Zambia, and 2017 in Lesotho. Since the survey, elections have been held in all but one of the 11 countries. Zambia is scheduled to hold its next national elections in August 2021.

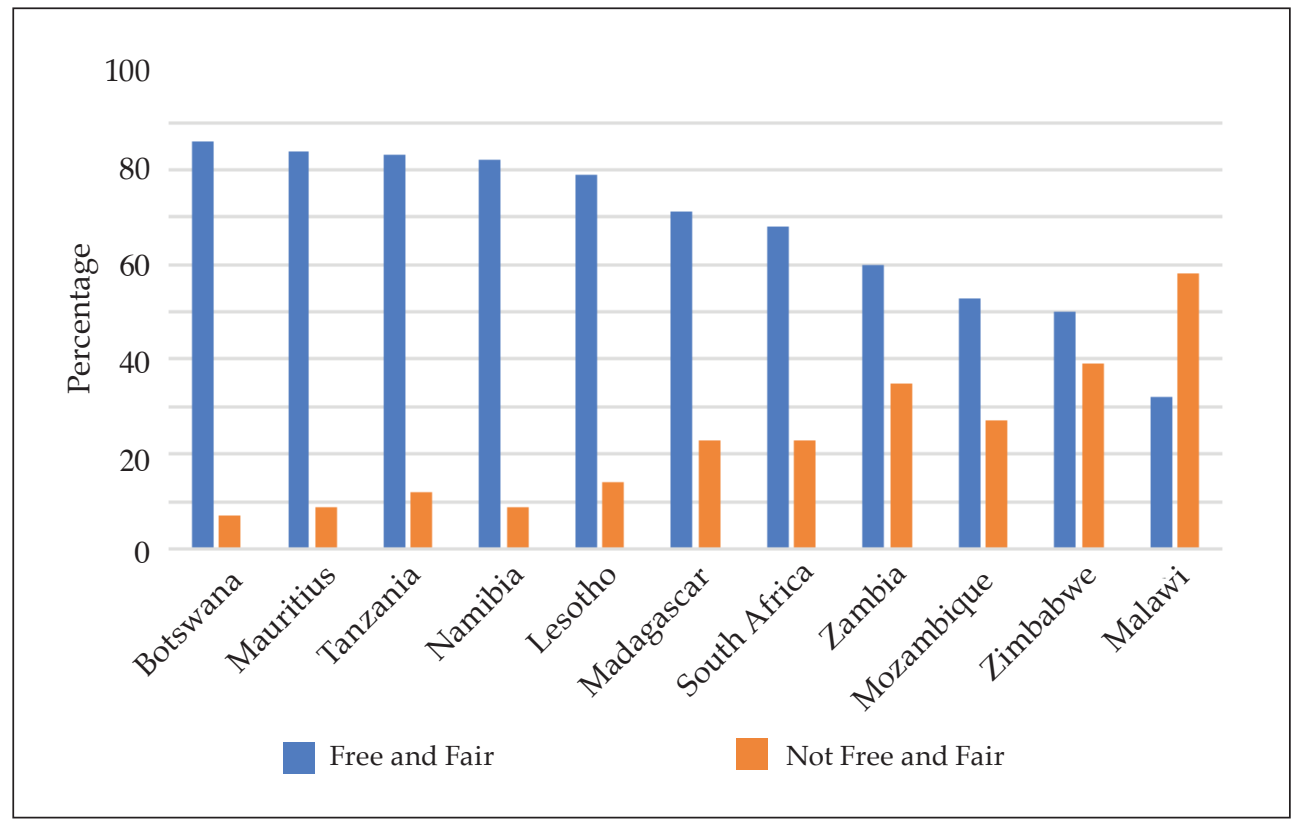

Figure 1: Freeness and fairness of last SADC elections 
The results show that citizens from across the SADC region generally rated the last elections held in their country to be free and fair. In five of the countries, more than three quarters of respondents rated the last national elections to be free and fair. At $86 \%$, Batswana citizens were the most satisfied with their last elections. In 10 of the 11 countries, at least half of all citizens surveyed rated the last national elections to be free and fair. Fewer citizens considered the last elections to have been 'not free and fair'. Malawi was the exception. Only $32 \%$ of Malawian respondents rated the 2014 elections to have been free and fair, while about 6 in 10 people (58\%) rated the elections to have been 'not free and fair'. The three countries discussed in this paper were among the four countries where citizens reported the highest levels of dissatisfaction with the freeness and fairness of the last national elections.

We now interrogate survey data for Zambia, Zimbabwe and Malawi in more detail to uncover trends over time. Analysing the freeness and fairness of the last national elections serves as a proxy for the credibility of elections. We also analyse trends in citizens' satisfaction with democracy. Doing so allows us to establish whether citizens' satisfaction with elections reflects broader evaluations of democracy, or the specific election, notwithstanding satisfaction with democracy. Because of our interest in the role of institutions that are crucial for conducting and legitimising elections, we also analyse trends in citizens' trust in electoral commissions and judiciaries.

\section{Freeness and Fairness of Elections}

Zambia, Zimbabwe and Malawi were all surveyed in the first round of the Afrobarometer surveys conducted between 1999 and 2001. With the exception of the second round conducted between 2002 and 2003, Afrobarometer surveys have consistently asked respondents to rate the freeness and fairness of the last elections. Figure 2 shows the trends from Round 1 to Round 7 for the three countries in question.

The data indicates that Zimbabweans have generally had low ratings for the freeness and fairness of their elections. This is not surprising, given that elections in Zimbabwe are often characterised by 'systematically high levels of violence' (Bleck \& van de Walle 2018, p. 97). Only in Round 6 (51\%) and Round 7 (50\%) did at least half the Zimbabwean survey respondents believe that their last elections were free and fair. In both surveys, Zimbabweans were rating the elections held in 2013. Notably, Round 5 results show that only $38 \%$ of Zimbabwean respondents believed that the contentious elections held in 2008 were free and fair. The controversy around these elections resulted in the formation of a Government of National Unity, brokered by the SADC, that brought together the ruling 
Zimbabwe African National Union-Patriotic Front (Zanu-PF) and two factions of the opposition Movement for Democratic Change (MDC).

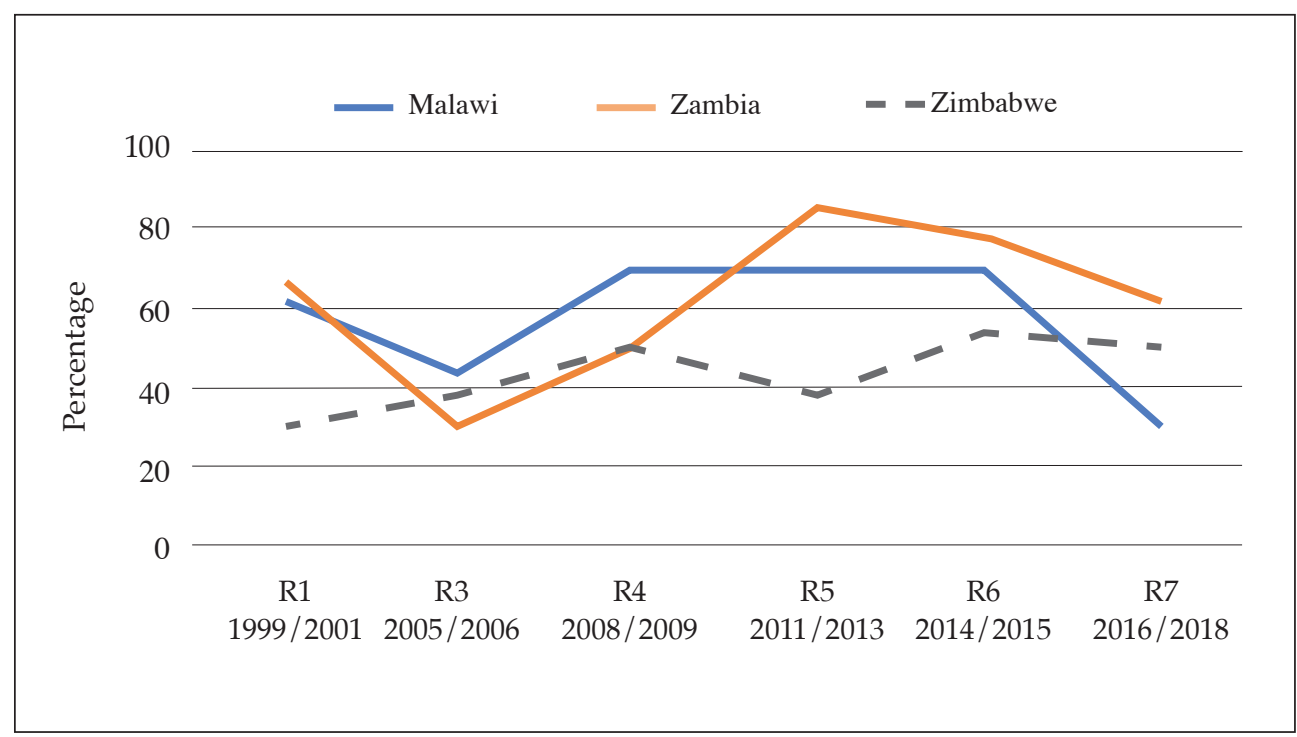

Figure 2: Freeness and fairness of last elections: Zambia, Zimbabwe and Malawi

Source: Afrobarometer Data, Rounds 1 and 3-7, 1999/ 2001 to 2016/2018

In Zambia and Malawi citizens were more likely to rate the last elections as free and fair when incumbents won with a commanding majority or when an electoral turnover occurred. For example, in Malawi's fifth and sixth surveys which both asked about the 2009 elections - about $70 \%$ of Malawians considered the last elections to have been free and fair. Bingu wa Mutharika had won the elections with $66 \%$ of the vote, the largest margin by which a candidate had won a presidential election in Malawi since the founding elections in 1994. In Zambia, the majority of respondents in the fifth and sixth surveys - both of which asked about the 2011 elections - rated the last elections to have been free and fair. The 2011 elections resulted in the defeat of an incumbent party and the election of the opposition Patriotic Front (PF) led by Michael Sata. In Round 6 which was conducted in 2012, a year after the election, $86 \%$ of Zambians regarded their election as free and fair.

By contrast, elections that were controversial, or in which the incumbent won narrowly, were rated lowly. Malawi's Round 7 data show that only 32\% of survey respondents regarded the 2014 election that elected Peter Mutharika 
to have been free and fair. Although Mutharika defeated the incumbent Joyce Banda, his closest rival was another opposition candidate, Lazarus Chakwera. Mutharika's Democratic Progressive Party (DPP) contested the elections from a rather bizarre position. The party had won the last elections in 2009 but was 'forced' into opposition when Bingu wa Mutharika died in office in 2012. He was succeeded by the DPP Vice President Joyce Banda, who had formed her own political party in 2011, despite remaining vice president of the country. ${ }^{2}$ Banda herself rejected the 2014 election results, suggesting they were rigged in favour of the DPP (Patel \& Wahman, 2015, pp. 84-85). Chakwera's Malawi Congress Party (MCP) and other opposition parties also called for a recount of the votes (ibid.). Commissioners on the Malawi Electoral Commission (MEC) were apparently split on a decision to conduct a full recount and took the issue to court. In the end, the High Court ordered the MEC to announce the results within eight days, while acknowledging the MEC's authority to undertake a recount (ibid.).

The results and aftermath of the elections helps to explain why only $32 \%$ of those surveyed rated the elections free and fair. Mutharika won the election with only $36 \%$ ahead of Chakwera, who obtained $28 \%$. The 11 candidates who competed against Mutharika won a combined $64 \%$ of valid votes. This provides some context to explain why $58 \%$ of Malawian citizens rated the elections as not free and not fair. The dissatisfaction with the 2014 election also helps to explain attitudes towards the outcome of the subsequent national elections in 2019, when the opposition rejected the results announced by the MEC and successfully challenged them in court. We discuss this in more detail later in this paper.

Similarly, in Zambia, the lowest ratings of the freeness and fairness of elections were recorded in Round 3 which asked about the 2001 elections. Only $29 \%$ of survey respondents believed that elections in 2001 were free and fair, a finding which is not surprising. Levy Mwanawasa won the 2001 presidential vote with $29 \%$, defeating his closest rival by only $2 \%$. Mwanawasa's 10 opponents won a combined $71 \%$ of the vote. Some presidential candidates challenged the results in the Supreme Court and although the court ruled in favour of Mwanawasa, it established that there had been 'several irregularities' in the presidential election (Sishuwa 2016a).

Taken together, the results on the freeness and fairness of the last election demonstrate that controversial elections potentially undermine the legitimacy

2 Joyce Banda was elected vice president of Malawi in 2009 as Bingu wa Mutharika's running mate. In 2010, Mutharika anointed his younger brother, Peter Mutharika, to succeed him as DPP leader at the end of his second term in 2014. Banda opposed this move because it frustrated her own political ambitions. She was expelled from the DPP in 2010 for opposing Mutharika's succession plan, but she remained republican vice president in accordance with the constitution. She formed the People's Party (PP) in 2011 and assumed the presidency in 2012 after the death of Mutharika, as the leader of the PP. The DPP was effectively relegated to the opposition. 
of the winning candidates. The formation of a Government of National Unity (GNU) in Zimbabwe, and the splits within Malawi's MEC and the court challenge regarding the results - which appear to have had implications for the elections held in 2019 - lead us to conclude that when citizens perceive that elections were not free and fair, this has the potential to undermine their confidence in future elections, unless meaningful reforms are implemented before the next election.

\section{Satisfaction with Democracy}

Across the seven rounds of Afrobarometer surveys, respondents were asked: 'overall, how satisfied are you with the way democracy works in [your country]?' We analyse this question to consider whether trends in the freeness and fairness of elections reveal broader trends in the satisfaction with democracy. The response categories were: 'not a democracy', 'not at all satisfied', 'not very satisfied', 'fairly satisfied', and 'very satisfied'. In Figure 3 below, we present the results for respondents who reported that they were 'fairly satisfied' or 'very satisfied' with the way democracy works. We use the two response categories as an indication of high levels of satisfaction.

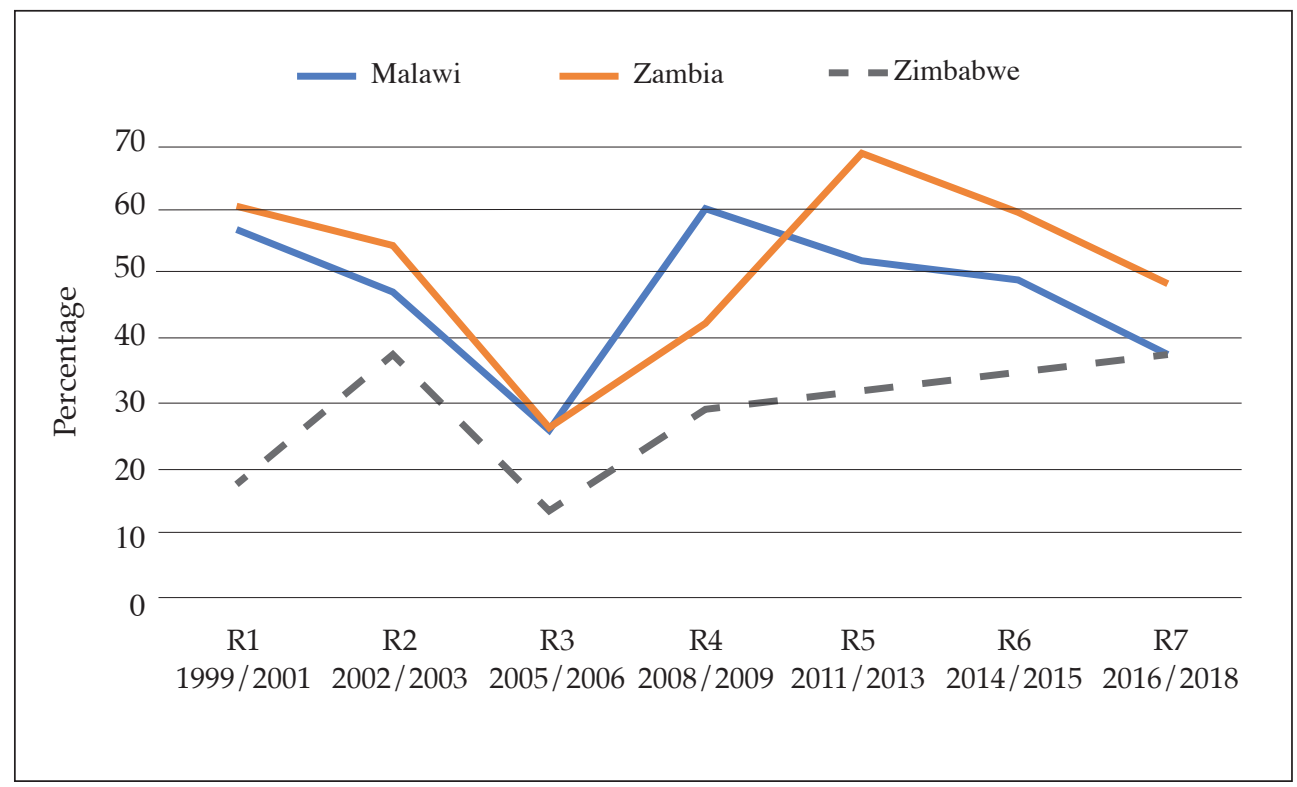

Figure 3: Satisfaction with democracy: Zambia, Zimbabwe and Malawi

Source: Afrobarometer Data, Rounds 1-7, 1999/ 2001 to 2016/ 2018 
The satisfaction with democracy amongst Zimbabweans was consistently below $40 \%$ and lower than the satisfaction amongst Malawians and Zambians. The exception was the Round 7 surveys, when satisfaction amongst Malawians fell to $37 \%$ from $49 \%$ in the preceding survey, and that of Zimbabweans peaked at $38 \%$. At the very low level of $14 \%$, satisfaction with democracy in Zimbabwe was at its lowest in the 2005/2006 survey which followed the 2002 elections. Elections held that year have been described as 'a turning point in Zimbabwe's electoral history, when the ruling Zanu-PF went from a 93\% majority in 1996 presidential vote to $52 \%$ in 2002' (Benjamin 2014). This dramatic decline in the ruling party's fortunes set the stage for even more violent and controversial elections in 2008 (ibid.). In Malawi, satisfaction with democracy peaked at 60\% in 2008/2009 after the 2004 elections, which were considered to be free and fair by $69 \%$ of survey respondents in the same round. The decline in satisfaction with democracy amongst Malawians dropped to its lowest (37\%) in 2016/2018 in the same survey, in which only $32 \%$ of citizens reported that the last national elections were free and fair. The results from Zambia show that satisfaction with democracy was at its lowest in 2005/2006 after the controversial 2001 elections and at its highest in 2011/2013 after the defeat of an incumbent in 2011.

These results reveal at least three patterns. First, there appears to be a positive correlation between citizens' ratings of the freeness and fairness of elections and their satisfaction with democracy across the three countries. Second, Zimbabwe is the laggard of the three countries, which is not surprising given its more authoritarian record and no previous democratic alternation of power. Lastly, Zambians generally have higher levels of satisfaction with democracy, peaking at $68 \%$, than Malawians and Zimbabweans. However, satisfaction declined to less than half (49\%) in Round 7. The most recent survey results also represented the first time in a decade that more than half of citizens surveyed in all three countries were dissatisfied with democracy.

\section{Trust in Electoral Commissions and Courts of Law}

Afrobarometer surveys asked respondents to report how much trust they had in public institutions, including the country's electoral commission and its courts of law. The question asked was: 'how much do you trust each of the following, or haven't you heard enough about them to say?' The response categories were: 'not at all, 'just 'a little', 'somewhat,' and 'a lot'. In Figure 4 below, we report the results of respondents who indicated that they trusted the electoral commission and the courts of law somewhat or a lot. We use the two response categories as measures of high levels of trust. Figure 4 shows results for trust in the electoral commission. 


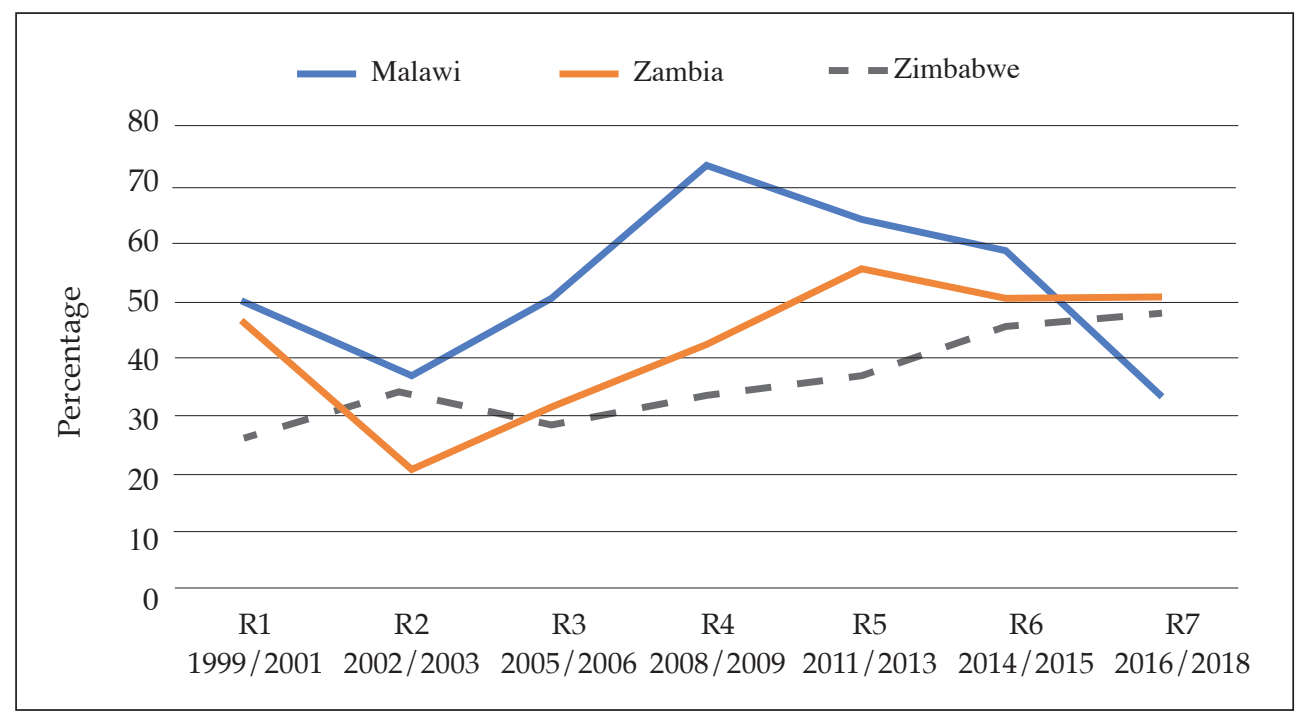

Figure 4: Trust in electoral commissions: Zambia, Zimbabwe and Malawi

Source: Afrobarometer Data, Rounds 1-7, 1999/ 2001 to 2016/ 2018

Between 1999/2000 and 2014/2015, Malawians had more trust in their electoral commission than Zambians and Zimbabweans had in theirs. Trust in the electoral commission was higher in Malawi than in Zambia, despite Zambians reporting higher levels of satisfaction with the quality of elections and of democracy. However, trust in the MEC plunged from 57\% in Round 6 to 33\% in Round 7. The data show that there was a significant decline in trust for the MEC after the contested election outcome in 2014. The results from Zambia show that trust in the Electoral Commission of Zambia (ECZ) was closely associated with ratings of the freeness and fairness of elections and satisfaction with democracy. Trust in the ECZ was at its lowest in 2002/2003, at 21\%, after the contested election outcome in 2001, and at its highest in 2011/2013, at 56\%, after the 2011 elections that brought the PF into power. Trust in the Zimbabwe Electoral Commission (ZEC) hovered between $26 \%$ and $36 \%$ between 1999/2001 and 2011/2013 but increased steadily after the 2013 elections, peaking at 50\% in Round 7, just before the 2018 elections.

Figure 5 below shows citizens' ratings of the courts of law. It shows that citizens from all three countries generally trusted their courts of law. Malawians had the highest average ratings of all three countries, reaching 81\% in 2011/2013. Zambia's rating ranged from a low of $49 \%$ in 2002/2003 and 2005/2006 to a high of $63 \%$ in 2008/2009 and again in 2016/2018. Zimbabwe's ratings began from a low of $43 \%$ in 1999/2001 and increased gradually across rounds reaching a high of $65 \%$ in $2016 / 2018$. 
These results reveal at least two broad patterns. First, citizens surveyed in Malawi, Zambia and Zimbabwe generally had more trust in their courts of law than they did in their electoral commissions. They also rated their courts more highly than they rated the freeness and fairness of elections and satisfaction with democracy. The relatively high ratings of the courts of law were specifically notable for Zimbabwe, which performed poorly on the other measures. Second, the results appear to show that there was an association between contested election outcomes and trust in the courts of law, which was surprising for Zimbabwe, given the extent to which the courts had lost their independence (Chifamba 2020). Trust in the Malawian courts declined considerably from $81 \%$ in 2011/2013 (Round 5) to $71 \%$ in 2014/2015 (Round 6) before declining further to 59\% in 2016/2018 (Round 7). The Round 6 survey was held after the 2009 elections and Round 7 survey after the 2014 elections.

Similarly, trust in the Zambian courts declined from 57\% in 1999/2001 to $49 \%$ in 2002/2003 and 2005/2006, after the 2001 elections. However, trust in the Zambian courts increased slightly from 59\% in 2014/2015 (Round 6) to 63\% in 2016/2018 (Round 7) even after disputed elections in 2016, in which the courts played an important role. These results suggest that citizens' ratings of the freeness and fairness of elections are not necessarily correlated with their trust in the courts, even though some trend patterns were observed. Moreover, these results are insufficient to establish a statistically significant relationship between trust in courts of law and ratings of elections and democracy.

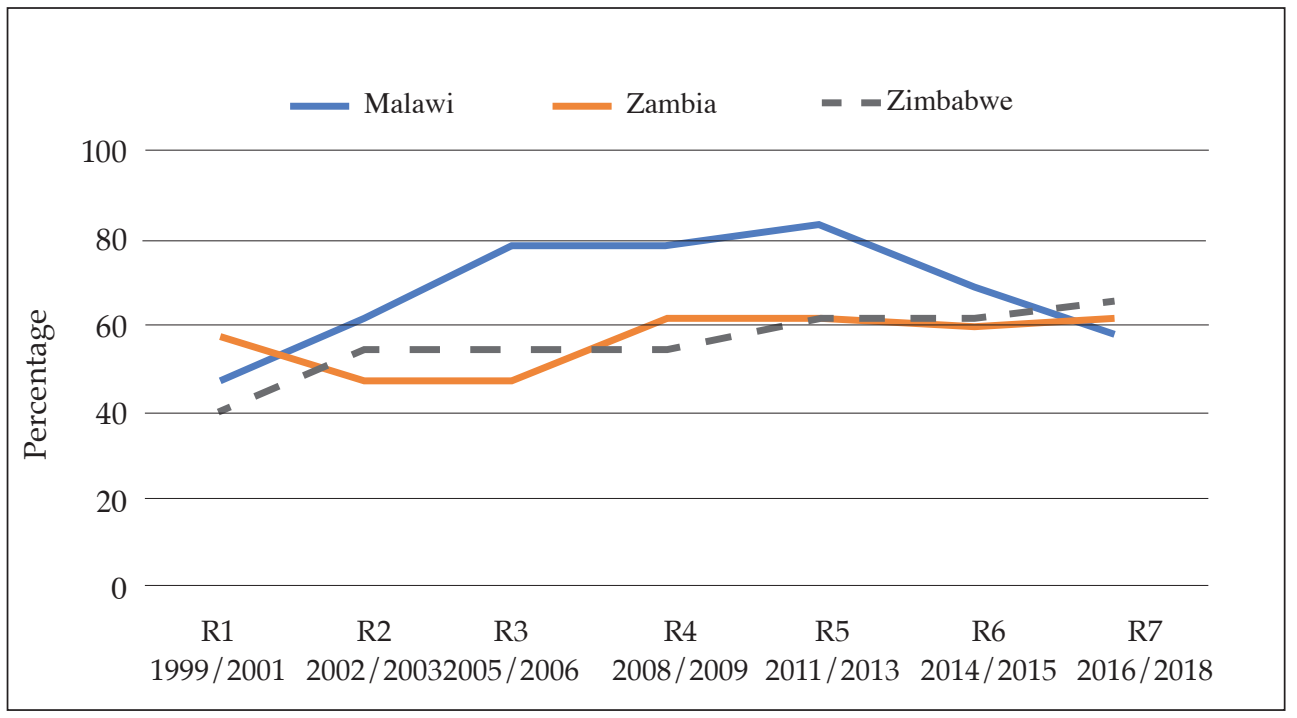

Figure 5: Trust in courts of law: Zambia, Zimbabwe, and Malawi 


\section{CASE STUDIES}

We now consider recent elections in Zambia, Zimbabwe, and Malawi, discussed in the order in which they held their last national election. Though it is difficult to generalise from these examples, we suggest that some common themes emerge.

\section{Zambia}

Zambia's most recent national elections were held in August 2016. They followed two consecutive competitive elections in 2011 and 2015. The 2011 national elections were won by the opposition PF led by Michael Sata, who defeated the governing Movement for Multiparty Democracy (MMD) led by Rupiah Banda. The January 2015 presidential by-election, which was triggered by the death in office of Sata in October 2014, was won by Edgar Lungu for the PF with a margin of 27000 votes against his closest rival Hakainde Hichilema of the United Party for National Development (UPND). The electoral turnover of 2011 and the narrow win for the PF in 2015, raised the possibility of another turnover in 2016. Various media and electoral observer reports showed that the ruling party deployed its incumbent advantage in a manner that disadvantaged the opposition. This included the use of state media in favour of the ruling party (Carter Center 2016); a decision by the president to maintain cabinet ministers in their positions after the dissolution of Parliament in May 2016 (which the courts subsequently ruled was in violation of the Constitution) (Lusaka Times 2016a); and the closure of the largest independent newspaper, The Post, which was critical of the ruling party, ostensibly for tax evasion (Siachiwena 2020; Sishuwa 2016b). There was also widespread political violence before voting, involving clashes between ruling and opposition party supporters. This prompted the ECZ chairperson to issue a statement on the eve of voting, noting that the ruling party had a 'bigger responsibility' for ensuring peace before and after the polls (Electoral Commission of Zambia 2016).

The UPND challenged the official results, claiming that irregularities had been uncovered in Lusaka's urban constituencies. These included the intimidation of the party's polling agents and the ECZ's failure to provide documents for party agents to record results. Furthermore, the UPND requested a recount of results for Lusaka because of an alleged discrepancy between the polling station totals and the constituency level result. The ECZ did not grant the recount and the UPND challenged the election results in the Constitutional Court, which had been created only a few months earlier. The Court spent 14 days addressing preliminary issues and, on 30 August, it extended hearing by five days, concluding on 8 September. Yet, when the Court reconvened on 5 September, it argued that its jurisdiction had ended and dismissed the UPND petition without hearing the case on its merits (Goldring \& Wahman 2016). It argued that the Constitution provided that an election petition must be heard within 14 days of being filed. 
Lungu was sworn in as president on 13 September without the Court ruling on the validity of his election. The Carter Center argued that 'the legal and judicial processes surrounding the presidential petitions failed to meet Zambia's national and international obligations under the Zambian constitution, the African Charter for Human and People's Rights, and the International Covenant on Civil and Political Rights to ensure due process, a fair hearing, and effective legal remedy' (Lusaka Times 2016b).

The UPND then argued that Lungu had not been legitimately elected because the Court had neither determined nor dismissed the merits of the petition. The post-election period was characterised by violence in parts of the country and 'further infringement of independent media' - who had their broadcasting licenses suspended for 'posing a risk to national security and peace' (Goldring \& Wahman 2016, pp. 116-117). Eight months after the 2016 elections, Hichilema was arrested and charged with treason when his convoy failed to give way to Lungu's presidential motorcade. Both leaders were heading to a traditional festival in the west of the country (Sishuwa 2017). Hichilema was also accused of planning to accord himself the status of Republican president at the festival. Hichilema remained in prison for four months until the intervention of domestic Catholic bishops and the Secretary-General of the Commonwealth, who prevailed upon Lungu to release his opponent.

The events in the aftermath of the 2016 elections can be attributed to the failures of the electoral commission and the courts to preside over the electoral process in a manner that satisfied both winners and losers. This had the effect of undermining Lungu's credibility - at least in the eyes of Hichilema and his supporters, who maintained that Lungu had not won. It was suggested at the time that Hichilema conceding defeat was crucial for his release from prison and for dialogue between the PF and UPND (News Diggers 2017). It appears that Hichilema's concession of defeat was necessary to provide credibility to the 2016 election process and to confer legitimacy to Lungu's election.

\section{Zimbabwe}

The most recent national election to be held in Zimbabwe took place at the end of July 2018, to elect both the president and parliament. It took place eight months after a coup that had removed Robert Mugabe, who had ruled first as prime minister and then as president, since independence. Nelson Chamisa of the Movement for Democratic Change Alliance (MDC-A) was the main challenger 
to Mugabe's successor, Emmerson Mnangagwa. ${ }^{3}$ Though his election to head the Alliance had been challenged within the MDC, many expected the MDC-A to win a free and fair presidential election. The constitution provided that unless a candidate won $50 \%$ of the vote, there would have to be a runoff election.

In the event, the Zimbabwe Electoral Commission (ZEC) announced that Mnangagwa obtained $50.8 \%$ of the vote, compared to Chamisa's $44.3 \%$ (there were other candidates in the election). The margin of Mnangagwa's victory, less than one percent of the $50 \%$ threshold to avoid a runoff, was so small that Chamisa argued the results were obtained by fraudulent counting and tallying of votes (Beardsworth, Cheeseman \& Tinhu 2019, p. 592). Not surprisingly, the result was contested both on the streets of Zimbabwe and in the country's courts.

Street protests were met with force by the police and army, who killed six unarmed protestors. Immediately after the election, the opposition MDC-A accused the governing Zanu-PF of rigging the vote and claimed that the figures announced by the ZEC did not tally with what was recorded on forms issued at each polling station. The MDC-A argued that provisions for assisting illiterate and blind voters had been manipulated. Observer missions also commented on assisted voting and bemoaned the ZEC's failure to release the total number of votes cast in this way (Beardsworth, Cheeseman \& Tinhu 2019, p. 593).

When Chamisa launched a court challenge of the result, the inauguration of Mnangagwa for a new term as president was postponed. At this point, the judiciary was no longer considered to be independent (Chifamba 2020). The Constitutional Court ruled on 24 August that the evidence of irregularities was not 'sufficient and credible'. Mnangagwa was finally inaugurated as president two days later. The MDC-A was unable to prove that polling irregularities were widespread enough to change the outcome of the vote (Beardsworth, Cheeseman \& Tinhu 2019, p. 592). The court's verdict on the election was widely rejected and the limited legitimacy the Mnangagwa government had gained has since declined further, partly because of the severe economic crisis that has brought the country to the brink of being a failed state (Ndlovu 2020).

\section{Malawi}

In Malawi there was sustained popular protest against the result of the presidential election that took place in May 2019. The election itself passed off peacefully and observer missions praised the MEC for its organisation of the polls, which included the use of a new biometric system of voting. When early results suggested that

3 Some advised Chamisa to boycott the election, arguing that to participate would help legitimate the 2017 coup, but he rejected that advice. He did ask for SADC and AU help to ensure the election was free and fair. 
Chakwera had not won the election, the MCP obtained a court injunction to delay the release of the final results because of alleged irregularities, and called for a recount in some districts. After the MEC announced that Mutharika had won $38.6 \%$ of the votes and Chakwera $35.4 \%$, Mutharika was sworn in for a second five-year term as president. Saulos Chilima, who came third in the presidential poll with $20.2 \%$ of the votes cast, rejected the result, and called for fresh elections.

In the aftermath of the election, opposition parties and the Human Rights Defenders Coalition (a civil society organisation) organised a series of nationwide protests which gained momentum as the months passed. Some turned violent and led to clashes with the police. The army was restrained in its response. The government tried to ban further protests, but in early August 2019 the High Court upheld the right to protest. In that month, the Constitutional Court started hearing an opposition application to have the results of the presidential election overturned. The protests continued into early 2020, until on 3 February the Constitutional Court ruled that the election had been flawed and that a new one should be held within 150 days.

In its 500-page ruling the court mentioned widespread irregularities, including duplicate forms and the use of Tippex correction fluid and missing signatures on some result sheets. The court also determined that 'majority' in Section 80 of the Constitution should be interpreted as a 50\% +1 majority electoral system, and it directed the National Assembly's Public Appointments Committee (PAC) to assess the competence of the MEC's commissioners. Parliament then passed electoral reform legislation to meet the court's requirements and, after some equivocation, set 23 June as the date for the new election. The PAC recommended that the MEC commissioners be replaced. Mutharika and the MEC rejected the court's ruling, and filed an appeal to the Supreme Court, arguing that there was no evidence that the outcome of the election had been affected.

Mutharika refused to assent to Parliament's electoral reform bills and to replace the MEC commissioners, and declared a state of disaster, without reference to parliament, over the coronavirus pandemic. His announcement of a three-week lockdown led to street protests in the major cities, and the High Court granted a temporary interdict against its implementation because the government had not announced any measures to cushion the impact. In May the Supreme Court rejected Mutharika's appeal and confirmed that the new election should go ahead (Moffat 2020).

In the run-up to the election Chakwera and Chilima forged a Tonse ('All of Us' in Chewa) Alliance, while Mutharika, who chose as his running-mate a son of a former president, cast doubt on whether a credible election could be held after the way in which the courts had overturned the 2019 election. Civil society had been energised and most Malawians were desperate for change. The MEC, under 
new and impressive leadership, had little time to organise the election, which took place as cases of COVID-19 were increasing; but the election nevertheless went ahead on 23 June with only local observers, and was, overall, peaceful.

Within days it was clear that it had been won decisively by Chakwera, who, the new MEC announced, won 58.6\% of the vote. Mutharika received fewer votes than in the 2019 election. Chakwera was swiftly sworn in as president, with Chilima as his vice president. This was the first time in Africa that a leader had won an election, the result had then been overturned, and the incumbent had been defeated in a subsequent election. The Malawi judiciary, along with the support the security forces gave to the protests, had played a crucial role in upholding democracy. In October 2020, the five judges who in February had annulled the result of the election, were awarded the Chatham House prize in recognition of their 'courage and independence in the defence of democracy'. At a time when standards of democratic governance are under threat not only in Africa, but in many democracies', said Chatham House, 'Malawi's constitutional court judges set an example for their peers across the world by upholding the centrality of the rule of law and separation of powers' (Matenga 2020; Moffat 2020).

\section{CONCLUSION}

The evidence from Afrobarometer suggests that as elections become more competitive, so the outcomes become more contested and the results are more likely to be perceived to be fraudulent, whether or not they are in fact significantly fraudulent. Yet those who assume power as a result of an election perceived to be flawed are likely to face legitimacy challenges. A desire to retain power may further undermine democratic gains and can lead to democratic breakdown unless meaningful reforms are implemented in the aftermath of flawed elections. When citizens in Zambia, Zimbabwe and Malawi believed that elections were not free and fair, this had implications for their satisfaction with democracy. Without meaningful political reforms, this lack of legitimacy can set the stage for subsequent elections to be even more contested and has the potential to undermine democracy.

Zambia goes to the polls in 2021 and observers of the pre-electoral environment are already pointing to a contested election outcome (Sishuwa 2020a; 2020b). The challenges Zambia is facing flow in part from the contested nature of the 2016 elections. The controversy that erupted around Malawi's 2019 election had roots in Peter Mutharika's controversial 2014 victory. His administration did little to win public trust or broaden electoral support and when his DPP won a second consecutive controversial election in 2019, the opposition, citizens and the courts all played roles in overturning the results, paving the way for Chakwera's MCP 
to win a fresh election. Had Mutharika held on to power, Malawi might have descended into chaos.

After controversial elections in Zimbabwe in 2008, a Global Political Agreement was reached, and a GNU formed. There were some political and constitutional reforms (including setting term limits), and these provided a semblance of economic stability (Raftopoulos 2013). These reforms appear to be part of the explanation as to why Zimbabweans rated freeness and fairness of the 2013 elections more positively than they did all the preceding elections since 1996. Relative satisfaction with democracy reached a peak, though the proportion of citizens who were satisfied with elections and democracy hardly breached the $50 \%$ barrier. Zimbabwe remains, for all intents and purposes, highly authoritarian, with very little democratic space. If trends from previous Afrobarometer surveys are indicative of future survey results, it is likely that Zimbabwean citizens would have rated the freeness and fairness of the 2018 elections much lower than they did elections that were held in 2013, and that any degree of satisfaction with democracy - always very low - would have dropped even further.

These examples demonstrate that in the absence of meaningful political and constitutional reforms, and a failure to stabilise economic conditions, incumbent parties with weak mandates - resulting from winning controversial elections may face stronger resistance from the opposition and citizens, or those parties may undermine democracy further to hold onto power. Either scenario has the potential to retard democracy significantly. The evidence from our three case studies suggests that contestation over election results has made the role of institutions such as electoral commissions and the courts more crucial than ever in the promotion of democracy. Where election outcomes are contested, even after court rulings, incumbents face serious legitimacy problems. These have implications for stability in the period after elections, and can undermine democracy in the long run rather than consolidate it. Such problems can result in an increase in authoritarianism to contain public discontent with the government. They may also include attempts to undermine the quality of future elections in a way that disadvantages the opposition further and undermines the ability of citizens to hold their government accountable. Such measures may take the form of constitutional amendments, for example abolishing or circumventing term limits, electoral reforms that may restrict the voters' roll, or the appointment of pro-ruling party officials to courts and electoral commissions.

Afrobarometer has found that where electoral reforms and assistance help citizens to feel better about the integrity of the electoral process, they become more supportive of government institutions and more willing to consent to official policies. Individuals often view similar election processes very differently; improvements in the quality of elections may not always be perceived as such, 
especially by the losers. Furthermore, even if losers can be convinced that the electoral procedures are fair, they may still hold residual negative attitudes. Even if losers can be convinced that they lost fair and square, they may still doubt the legitimacy of government institutions, at least in comparison to winners. Where losers withdraw their consent, they may act against a government that they deem illegitimate, if they are given an opportunity. In Lesotho, the introduction of a mixed electoral system meant that losing parties were less likely to be critical of government legitimacy (Matlosa 2010; Moehler 2013).

Processes should be put in place to resolve disputes arising from controversial or fraudulent elections, otherwise countries may slide from democracy to autocracy. Observers and institutions committed to promoting democracy in the region should support measures to meet the challenges of disputed elections. Where mechanisms to promote such reforms are lacking, international partners should not merely observe the voting process. Hichilema (2020) suggested that they should, in addition, actively assist the broader process of strengthening those institutions that help ensure legitimate elections.

Beardsworth, N, Cheeseman, N \& Tinhu, S 2019, 'Zimbabwe: The coup that never was, and the election that could have been', African Affairs, vol. 118, no.472, pp. 580--596.

Benjamin, C 2014, 'Khampepe: Zim's 2002 elections not free and fair', In Mail $\mathcal{E}$ Guardian, 14 November. https://mg.co.za/article/2014-11-14-khampepezimbabwes-2002-elections-not-free-and-fair/

Bleck, J, \& van de Walle, N 2018, Electoral Politics in Africa since 1990: Continuity in Change, Cambridge University Press, Cambridge.

Bogaards, M 2013, 'Exchange: Reexamining African Elections', Journal of Democracy, vol. 24, no 4, pp. 151-160.

Bogaards, M \& Elischer, S 2016, 'Competitive authoritarianism in Africa revisited', Z Vgl Polit Wiss, vol 10, no. 5, pp. 5-18.

Carter Center 2016,'Carter Center Expresses Concerns Regarding Pre-Election Environment and Urges Patience While Results Come In'. Retrieved from https://www.cartercenter.org/resources/pdfs/news/peace_publciations/ election_reports/Zambia-prelim081516.pdf

Chifamba, M 2020, 'Zimbabwe: Mnangagwa's Capture of Judiciary a Red Flag for State Failure', The Africa Report, 23 November. Retrieved from https://www. theafricareport.com/51602/zimbabwe-mnangagwas-capture-of-judiciary-ared-flag-for-state-failure/ 
Coltart, D 2016, The Struggle Continues: 50 Years of Tyranny in Zimbabwe, Jacana Media, Auckland Park.

Diamond, L 2002, 'Thinking About Hybrid Regimes', Journal of Democracy, vol. 13, no. 2, 21-35.

Electoral Commission of Zambia 2016. ECZ Chairperson's pre-election statement, 9 August. Retrieved from: http://ecz-news.com/news/2016/08/page/2/

Elklit, J \& Reynolds, A 2002, 'The Impact of Election Administration on the Legitimacy of Emerging Democracies: A New Comparative Research Agenda', Commonwealth and Comparative Politics, vol. 40, no. 2, pp. 86-119.

Erlich, A, \& Kerr, N 2016, 'The local mwananchi has lost trust': design, transition and legitimacy in Kenyans' election management', Journal of Modern African Studies, vol. 54, no. 4, pp. 671-702.

Freedom House, 2020, https://freedomhouse.org/countries/freedom-world/scores. Goldring, E, \& Wahman, M 2016, 'Democracy in Reverse: The 2016 General Election in Zambia', Africa Spectrum, vol. 51, no. 3, pp. 107-121.

Hichelema, H 2020, 'Lessons from Malawi's election for southern Africa's opposition', Webinar, Brenthurst Foundation, 24 July.

Levitsky, S \& Way, L 2010, Competitive Authoritarianism, Cambridge University Press, Cambridge.

Lindberg, S 2004, 'The Democratic Qualities of Competitive Elections: Participation, Competition and Legitimacy', Commonwealth \& Comparative Politics, vol 42, no. 1, pp. 61-105.

Lindberg, S (ed.) 2009, 'Introduction' in Democratization by Elections: A New Mode of Transition?', Johns Hopkins University Press, Baltimore, MD.

Lockwood, S.J \& Krönke, M. 2020, ‘Do electoral systems affect how citizens hold their government accountable? Evidence from Africa', Democratization, DOI: 10.1080/13510347.2020.1840556

Lusaka Times 2016a, 'Constitutional Court Orders Ministers to Vacate Offices,' 8 August. Retrieved from: https://www.lusakatimes.com/2016/08/08/ constitutional-court-orders-ministers-vacate-offices/

Lusaka Times 2016b, 'Carter Center Expresses Deep Concern about Zambia's 2016 Electoral Process and Democratic Institutions,' 15 September. Retrieved from: https://www.lusakatimes.com/2016/09/15/carter-center-expresses-deepconcern-zambias-2016-electoral-process-democratic-institutions/

Matenga, G 2020, 'Malawi court judges win global prize'. Retrieved from: https:// mg.co.za/africa/2020-10-28-malawi-court-judges-win-global-prize/

Matlosa, K 2010, 'The Role of the Southern African Development Community in Mediating Post-election Conflicts. Case Studies of Lesotho and Zimbabwe' in K Matlosa, G Khadiagala and V Shale (eds), When Elephants Fight. Preventing 
and Resolving Election-Related Conflicts in Africa, Electoral Institute for the Sustainability of Democracy in Africa (EISA), Johannesburg.

Moehler, D \& Lindberg, S 2009, 'Narrowing the legitimacy gap: Turnovers as a cause of democratic consolidation', Journal of Politics, vol. 71, no. 4, pp. 1448-1466.

Moehler, D 2013, 'Free and Fair or Fraudulent and Forged: elections and legitimacy in Africa', In M Bratton (ed.), Voting and Democratic Citizenship in Africa, Lynne Rienner Publishers, Boulder, CO.

Moffat, C 2020, 'Malawi Elections Provide a Global Lesson in Democracy', Mail and Guardian, 23 November. Retrieved from https://mg.co.za/thoughtleader/202011-23-malawi-elections-provide-a-global-lesson-in-democracy/.

Ndlovu, M 2020, "The Politics of Selective Condemnation: "Silencing the Guns" in Zimbabwe during a Pandemic', Maverick Citizen, 4 August. Retrieved from https://www.dailymaverick.co.za/article/2020-08-04-the-politicsof-selective-condemnation-silencing-the-guns-in-zimbabwe-during-apandemic/.

News Diggers, 2017, 'HH must first accept defeat before dialogue - RB.' Retrieved from https://diggers.news/local/2017/06/18/hh-must-first-accept-defeatbefore-dialogue-rb/

Patel, N \& Wahman, M 2015, ‘The Presidential, Parliamentary and Local Elections in Malawi, May 2014', Africa Spectrum, vol. 50, no. 1, pp. 79-92.

Raftopoulos, B (ed.) 2013, The Hard Road to Reform: The Politics of Zimbabwe's Global Political Agreement, Weaver Press, Harare.

Schedler, A 2002, 'The Menu of Manipulation', Journal of Democracy, vol. 13, no. 2, pp. 36-50.

Siachiwena, H 2020, 'The 2011 - 2016 Zambian elections: Incumbency, Turnovers and Democratic Consolidation', In T Banda, O Kaaba, M Hinfelaar and M Ndulo (eds). Democracy and Electoral Politics in Zambia, Brill, Leiden and Boston.

Sishuwa, S 2016a, 'I am Zambia's Redeemer: Populism and the Rise of Michael Sata, 1955-2011', PhD. thesis, University of Oxford, Oxford.

Sishuwa, S. 2016b, 'Zambia's 2016 Elections: Is a Disputed Outcome Now Inevitable?', African Arguments. Retrieved from africanarguments.org/2016/06/01/ zambias-2016-elections.

Sishuwa, S. 2017, ‘The Real Reason Zambia's Opposition Leader was Released from Jail', African Arguments. Retrieved from https://africanarguments. org/2017/09/19/the-real-reasons-zambia-opposition-leader-was-releasedfrom-jail/

Sishuwa S 2020a, 'In Zambia, Covid-19 has claimed democracy, not human life', Mail $\mathcal{E}$ Guardian. Retrieved from https://mg.co.za/africa/2020-06-15-in-zambiacovid-19-has-claimed-democracy-not-human-life 
Sishuwa, S 2020b, 'This is how Lungu is planning to rig Zambia's 2021 election', Mail $\mathcal{E}$ Guardian. Retrieved from: https://mg.co.za/africa/2020-09-25-this-is-howlungu-is-planning-to-rig-zambias-2021-general-election/

Wahman, M 2014, 'Democratization and electoral turnovers in sub-Saharan Africa and beyond, Democratization', vol. 21, no. 2, pp. 220-243.

Williamson, S 2020, 'Elections, legitimacy and compliance in authoritarian regimes: evidence from the Arab world', Working Paper (under review). Retrieved from: https://static1.squarespace.com/static/5b23cff07c9327b8cde5c995/t/5 ed015863dbf3e290e8c40bd/1590695303502/Elections-Autocracy-LegitimacyWebsite.pdf 


\title{
ZIMBABWE'S 2018 HARMONISED ELECTIONS An Assessment of Credibility
}

\author{
Rekai Rusinga \\ Rekai Rusinga is Elections Monitoring and Observation Officer with the \\ Zimbabwe Election Support Network
}

\begin{abstract}
This paper assesses the credibility of Zimbabwe's 2018 harmonised elections using an electoral cycle approach, arguing that the free expression of voters' choice is a sine qua non for credibility. A study of Election Observer Missions' reports (EOMs), media reports, and observation in relation to the 2018 elections, points to inadequate legal reforms; questionable independence and impartiality of the Elections Management Body (EMB); media bias; partisan distribution of aid; abuse of state resources; vote buying; partisan involvement of traditional leaders and of the military; intimidation; and suspicious results management. The paper concludes that the 2018 harmonised elections did not pass the credibility test owing to the cumulative effect of structural inadequacies. There is thus a need to comprehensively reform Zimbabwe's electoral laws, improve elections administration, and ensure a level playing field for contestants by addressing the political environment within which elections are held.
\end{abstract}

Keywords: voters' choice; harmonised elections; credibility; Zanu-PF; militarisation

\section{INTRODUCTION}

This paper assesses the credibility of Zimbabwe's 2018 harmonised elections in relation to the question: To what extent can the outcome convincingly reflect the free choice of the voters? The question is fundamental in that the basic purpose of an election is to afford the electorate an opportunity to choose leaders rather than have leaders imposed on them. An election based on induced preferences or manipulation of any kind cannot be adjudged credible as it cannot reflect the will of the people. In short, the free choice of voters is a sin qua non for a credible election. 
The paper adopts the electoral cycle framework in which elections are considered to be a process encompassing the pre-election, election, and postelection periods. What happens both during and between political elections regarding the legal framework and election administration processes throughout the cycle affects the quality of an election. The thesis of the paper is that the 2018 harmonised elections did not pass the credibility test due to various factors. These include the questionable independence of the EMB; media bias; the partisan role of traditional leaders and of the military; politicisation of aid, abuse of State resources, and vote buying; intimidation; and suspicious results management.

\section{LITERATURE REVIEW}

There has been a significant rise in multiparty elections for the executive in Africa over the past two decades (da Rocha \& Khuon 2018, p. 153), but the continent has had mixed experiences with elections. Credible elections have included Liberia's first post-conflict election in 2005 and Sierra Leone's first election in the absence of peacekeeping troops in 2007 (Sweeney 2014, p. 3). Ghana's 2008 presidential election reaffirmed that country's successful democracy after the ruling party, which had won the first round, handed over power to the opposition following the latter's victory in a runoff vote (ibid.). Botswana, Namibia and South Africa hold elections that are internationally recognised as free and fair (Soler-Crespo 2019, p. 10).

However, the United Nations Economic Commission for Africa (UNECA) contends that the increased regularity of multiparty elections in Africa has not necessarily enhanced their value (UNECA 2013, p. 1). Even in countries considered models of democracy in Africa, there have been concerns about the denial of rights, manipulation of votes and prevention of individuals, groups, and associations from contributing to and engaging in electoral democracy (Afolabi 2017, p. 14).

A common observation regarding elections in Africa has been the lack of integrity and credibility (Afolabi 2017, p. 13). Electoral malpractices have included vote-buying, politically-motivated violence, intimidation, sectarian mobilisation, and mud-slinging as different political parties seek to outwit each other (Chikwanha \& Masunungure cited by Mapuva 2013, p. 88; UNECA 2013, p. 1). Incumbency and abuse of state resources have also been exploited in pursuit of victory (da Rocha \& Khuon 2018, p. 153; Cheeseman cited by Bob-Milliar \& Paller 2018, p.7). This was true even for Ghana, where prior to 2016, no opposition candidate had defeated an incumbent presidential candidate in the context of a strong incumbency bias (Bob-Milliar \& Paller 2018, p.11).

This paper seeks to add a voice to the challenges of electoral democracy in Africa, focusing on Zimbabwe's 2018 harmonised elections. Zanu-PF has been 
declared winner in successive elections despite contestations. In the Economic Intelligence Unit's 2018 rankings, Zimbabwe comes after South Africa, Namibia, Tanzania, Mozambique, and Angola because of decades of government violence and repression against opposition parties, and discredited electoral outcomes (Soler-Crespo 2019, p. 8).

\section{BACKGROUND TO THE ZIMBABWE 2018 HARMONISED ELECTIONS}

Zanu-PF victories have, since 1980, been ensured by several factors: government control of the electoral machinery, the media and ideology; overturning election results (in 2008); the curtailment of fundamental freedoms and massive constraints on the opposition; violence and intimidation with military backing; the benefits of incumbency and abuse of state resources as well as vote buying; and the manipulation of traditional leaders. Zanu-PF's hegemony has also been partly due to the first-past-the-post electoral system used since 1985. This was after proportional representation was abandoned as it was felt, at that time, to prevent a clear victory by African nationalists, thus enabling opposition parties to form a coalition government (Sithole \& Makumbe 1997, p. 125). The winner-takes-all system has guaranteed Zanu-PF plurality rather than majority victory in seats and disposed the opposition towards intra-party competition rather than coalition against Zanu-PF.

\section{Peculiarities of the 2018 Harmonised Elections}

Vicious factionalism in Zanu-PF led to the intervention of the military and the activation of an impeachment process in Parliament, culminating in the resignation of long-serving Robert Mugabe on 21 November 2018. Emmerson Mnangagwa, sworn in on 24 November 2017, replaced Mugabe and made repeated promises of free, fair, credible, and peaceful elections. In the main opposition, the Movement for Democratic Change (MDC-T), Nelson Chamisa controversially succeeded Morgan Tsvangirai, who had died on 14 February 2018. There were contestations regarding which of the three MDC-T vice presidents was to take over, resulting in a party split.

Opposition parties had hoped to increase their prospects of dethroning Zanu-PF by forming a coalition (Mungwari \& Vhutuza 2017, pp. 172, 173). Fragmentation cost the opposition the presidency in March 2008 when the main opposition MDC under Morgan Tsvangirai scored a plurality but fell short of a majority (Afrobarometer 2018, p. 1). However, attempts at an umbrella coalition failed ahead of the 2018 elections, and instead the largest splinter became the Chamisa-led MDC Alliance. 
The elections also recorded the highest number of parties and candidates to contest in the presidential, National Assembly, and local authority elections. However, these were essentially a contest between Zanu-PF and the MDC Alliance, reflecting the binary nature of electoral politics that had hitherto been dominated by Zanu-PF and the MDC. ${ }^{1}$

The elections were held in a largely peaceful environment. Fundamental freedoms of movement, speech, and association were respected more than in previous elections, largely without the selective application of restrictive legislation such as Public Order and Security Act (POSA) and Access to Information and Protection of Privacy Act (AIPPA) (Catholic Commission for Justice and Peace (2018, p. iv). As a result, political parties held virtually unhindered rallies across the country. One notable exception was when former vice president and National People's Party leader, Joice Mujuru, and her supporters were attacked by suspected Zanu-PF activists in Harare on 1 February (NewsDay February 2018). There were also instances where people were forced to attend or blocked from attending rallies, and supporters of opposing parties disrupted rivals' rallies (Zimbabwe Election Support Network (ZESN) 2018a). Invited observers included those from the Commonwealth and European Union - a wider array than since the early 2000s.

In a bid to minimise the perception that it was biased, the Zimbabwe Electoral Commission (ZEC) also tried to engage stakeholders, particularly political parties, through Multi-Party Liaison Committees (MPLCs) (The Sunday Mail 2017). However, the MPLCs met infrequently at national level and generally did not serve as a forum where decisions were made, undermining their effectiveness (ZIEOM 2018, p. 9). Some political parties also expressed dissatisfaction with the manner in which ZEC conducted itself and reacted to issues during meetings (ibid.).

The adoption of biometric voters' registration (BVR) produced a new and cleaner voters' roll (ZESN 2018b). The Electoral Act Amendment of 28 May 2018 introduced a raft of significant amendments, including:

- the adoption of polling station-based voting (previously, voting was ward-based meaning a voter could vote from any polling station in their ward, sometimes resulting in multiple voting);

- a 10\% threshold for the number of ballot papers to be printed in excess of the number of registered voters; and

- a detailed code of conduct for political parties, candidates, and other stakeholders.

1 Despite splits at different junctures, a splinter group of the MDC would always be the main opposition in elections. In the 2018 harmonised elections, the Khupe-led MDC-T was far less popular than the MDC Alliance led by Chamisa. 
However, the extent to which polling station-based voting would be productive in Zimbabwe remained questionable. Addressing Zanu-PF rallies ahead of by-elections in 2015 and 2016, Mnangagwa and Saviour Kasukuwere threatened retribution, telling voters that polling station-based voting would expose which community had sold out (The Standard, 24 January 2016; VOA 2 December 2015).

\section{Lack of Political Will to Reform}

Although reforms were instituted as noted above, individuals in the ruling party were reluctant to allow electoral reforms. After the 2013 harmonised elections, the opposition decided not to participate in by-elections without electoral reforms. In 2016, opposition parties agreed that reforms were needed to guarantee the secrecy and security of the vote and the voter, entailing amendments to the Constitution and laws to facilitate free and fair elections (Charamba 2016). This was expressed through a unified platform they had created to push for electoral system reforms, the National Electoral Reform Agenda (NERA).

In April 2018, the MDC-T Secretary General Douglas Mwonzora agreed to amendments to the Electoral Act to level the playing field, but argued that these proposed amendments did not touch the 'real fundamentals' in terms of election management. He singled out the ZEC's logistics committee which he said remained in the hands of the state, run by officials seconded from state security (Chidza 2018). Mwonzora called for the demilitarisation of the committee if elections were to be truly credible, free, and fair.

However, in June 2015 Mnangagwa had told a rally in Manicaland that Zanu-PF would not agree to reforms but would go ahead with elections and continue to rule forever (Zulu 2015). For Zanu-PF, the 2013 Constitution had fully addressed electoral reform issues. Party stalwarts Patrick Chinamasa, Jonathan Moyo, and Ziyambi Ziyambi agreed that no legislative reforms were needed as the law allowed for democratic elections. Moyo and Chinamasa noted that the Constitution was negotiated with opposition involvement. Moyo added that a majority had supported the Constitution in a referendum (The Herald 2016; The Chronicle 2016), interpreting the call for reforms as 'clear codes to say come with reforms that will ensure that you are out' (The Chronicle 2016). Echoing Moyo's sentiments, Paul Mangwana, then Zanu-PF's Deputy Secretary for Legal Affairs, said the opposition should push for electoral reforms as Zanu-PF could not be expected to 'reform itself out of power' (Southern African Political Economy Series (SAPES) and National Endowment for Democracy (NED) Conference 2017).

Despite the imminent harmonised elections, the ruling party remained adamant that no electoral reforms were needed. Ziyambi, minister of Justice, 
Legal, and Parliamentary Affairs, said that there was no need to 'just waste resources doing cosmetic changes to the legislation on issues that are already materially covered by the existing legislation' (NewsDay 2018). Closer to the election, Mnangagwa said of the opposition march on 4 June 2018 demanding electoral reforms 'They are enjoying democracy which exists in this country. I think they are so happy that there is an environment where they can express themselves right, left and centre' (The Herald 2018). He said that the playing field was 'perfectly level' as he had recently signed into law the 28 May Electoral Act Amendment. The pertinent question was the extent to which piecemeal eleventhhour reforms, eventually agreed to by a reluctant Zanu-PF, would have a material effect on the elections.

\section{ASSESSMENT OF THE CREDIBILITY OF THE 2018 HARMONISED ELECTIONS}

This paper does not substantiate the 'theft by numbers' ${ }^{2}$ thesis. The MDC Alliance did not deploy party agents nor attempt a Parallel Vote Tabulation (PVT), but could not support this claim against Zanu-PF when it challenged their victory in court. The paper therefore focuses on other aspects that may have worked against the free choice of voters.

\section{Electoral Malpractices in By-elections}

Following the electoral cycle approach, the paper starts with the by-elections held after the 2013 harmonised elections. Reports by observer groups indicate a number of irregularities including incidents of partisan distribution of food aid; the misuse of state resources by the incumbent; the partisan role of traditional leaders in favour of Zanu-PF; and intimidation (ZESN 2015, p. 14; ZESN 2017, p. 14; CCJP 2018). Some of these malpractices had been observed in previous elections and others were a precursor to what would happen closer to the 2018 harmonised elections.

\section{Questionable Independence and Impartiality of the Elections Management Body}

An EMB that is not independent and impartial cannot be trusted to respect the voters' choice or election outcome if the favourite does not emerge victorious.

2 The phrase was used by Makumbe (2009) arguing that ZEC manipulated figures to ensure a victory for Zanu-PF in 2008. 
The non-partisanship of independent commissions is guaranteed in Section 236 of Zimbabwe's Constitution.

Public confidence is critical to the integrity of elections; perceptions matter in elections. Yet ZEC suffers from residual mistrust because of the manner in which it has conducted previous elections. Makumbe (2009, p. 132) asserts that ZEC's establishment was controversial from the outset and the commission was biased towards Zanu-PF. Ahead of the 2018 elections, a significant number of stakeholders perceived ZEC as impartial towards Zanu-PF (ZESN 2018d; ZESN 2018e; Afrobarometer 2018, p. 35). Executive interference in ZEC (ZESN 2018c, p. 21) was of concern. But perhaps the most contentious issue was the militarisation of the ZEC which opposition political parties demonstrated against between 2016 and 2017, claiming that it compromised the independence of the commission. ${ }^{3}$ This was denied by Chinamasa who argued that there 'never have been serving members of the uniformed forces working for ZEC' (Charamba 2016).

The militarisation of the EMB dates back to the Electoral Supervisory Commission (ESC) that administered elections before the formation of ZEC. Major-General Douglas Nyikayaramba was appointed as head of the ESC and was said to have resigned from the army, yet he later returned to his old job. The ZEC conceded less than 15\% presence of former military personnel (NewsDay 2018). The appointment of former army Major Utoile Silaigwana as Chief Elections Officer in 2018 further heightened concerns about ZEC's militarisation. The Crisis in Zimbabwe Coalition (2018) expressed concern that Silaigwana was among those leading to the militarisation of the EMB as he had joined the ESC when he was still in the army. Apart from his military background, CiZC also expressed concerns that as part of the 2008 ZEC secretariat, Silaigwana was complicit in the commission withholding the March 2008 election results for nearly a month, resulting in a heavily contested electoral outcome.

Constance Chigwamba, who was replaced by Silaigwana, had her employment contract terminated five months before the election. She returned to the public service with the unanimous agreement of ZEC commissioners that the move would guarantee the independence of the commission (DailyNews 2018). Chigwamba's resignation followed that of Justice Rita Makarau as ZEC chairperson under unclear circumstances three months previously, on 7 December 2017. Justice Priscilla Chigumba, who replaced Makarau, argued that the ZEC policy did not preclude the commission from employing retired and inactive former military members. However, the history and loyalty of such persons justifiably raises fears, particularly after the controversial military intervention of November 2017 revealed the military's role in elections.

3 As of February 2017, NERA consisted of 13 opposition political parties. 
Confirming the militarisation of the commission, the former Minister of Home Affairs, Dumiso Dabengwa, averred:

The staffing in ZEC comprises people who are and have been in security, people who take orders to do those vote manipulations... it is the army, police, and other security personnel that actually administer the process of voting. We also recommend that their influence and participation in elections should be done away with such that we have proper elections that are run by an independent administration.

(Muvundusi 2017)

Another former Zanu-PF senior cadre, Rugare Gumbo, agreed, saying: 'We need professional people handling the elections, it's time all the people from the military and state security get out of election management' (DailyNews 22 May 2017). The involvement of the military in elections was also confirmed by Namibian President Hage Geingob, who indicated that Mnangagwa and the military had trained them on elections when they visited Zimbabwe on a learning mission shortly before gaining independence (Mhlanga 2017).

In the ZIEOM assessment, the presence of a significant number of former military personnel in ZEC management positions undermined trust in the EMB (2018, p. 9). Not surprisingly, the African Union Election Observation Mission (AUEOM) found a lack of confidence among many opposition party members regarding the impartiality of ZEC and its ability to conduct transparent and credible elections (AUEOM 2018, pp. 3-4).

\section{Media Bias}

According to Makumbe, 'the mass media have the task of effectively and impartially informing the electorate on the character, views, policies and other relevant details of candidates and/or their parties' (2006, p. 49). Section 160J of the Electoral Act of Zimbabwe requires all media outlets, both print and electronic, to ensure that all political parties and candidates are treated equitably, in terms of the timing and prominence of coverage accorded to them, in the news media (Media Monitors 2018c, p. 49). This was not complied with in the 2018 harmonised elections.

There was no equal access to media for all parties and the coverage of political parties on the public broadcaster was not equal (CCJP 2018, p. 15; Eminent Persons Observer Mission Report to the Zimbabwe Harmonised Elections 2018, p. 16; SADC PF EOM 2018, p. 8). The ZIEOM observed that state-owned media 
showed systematic and extreme bias in favour of the ruling party (2018, pp. 9-10). Coverage on radio and national television was disproportionately biased towards the ruling party and unfair towards the opposition (Media Monitors 2018c, pp. 50). In six weeks, Zanu-PF had 52\% coverage; MDC Alliance 19\%; while $22 \%$ went to the other 47 political parties that were also covered (ibid.). Table 1 below shows the coverage of presidential candidates in all media while Table 2 shows media coverage of Zanu-PF and MDC Alliance in state-owned media.

Table 1: Coverage of presidential candidates in all media

\begin{tabular}{|l|l|c|}
\hline Candidate & Political party & \% coverage \\
\hline Emmerson Mnangagwa & Zanu-PF & 57 \\
\hline Nelson Chamisa & MDC Alliance & 15 \\
\hline Nkosana Moyo & APA & 23 \\
\hline Others & & $\mathbf{1 0 0}$ \\
\hline Total & & \\
\hline
\end{tabular}

Source: Media Monitors 2018

Table 2: Parties' coverage in the State-owned media

\begin{tabular}{|l|c|c|}
\hline Political party & \multicolumn{2}{|c|}{$\%$ coverage } \\
\hline & State-run newspapers & ZBC \\
\hline Zanu-PF & 76 & 48 \\
\hline MDC Alliance & 17 & 6 \\
\hline
\end{tabular}

Source: Media Monitors 2018

Tables 1 and 2 clearly indicate that Zanu-PF received disproportionately high media coverage. Throughout the campaign period, Zanu-PF adverts predominated on all radio stations and the party accounted for $93 \%$ of advertising space on ZBC stations (ibid.). Zanu-PF received largely positive coverage in the governmentcontrolled media whereas MDC Alliance received more negative coverage than other parties (ibid.). The MDC Alliance presidential candidate was often portrayed as a liar and immature. Mainstream media, both private and public, print and electronic media was polarised in its election coverage (SADC PF EOM 2018, p. 8). A media monitoring committee established by the ZEC was largely ineffective in identifying offences and in enforcement, and therefore did not affect coverage (ZIEOM 2018, p. 10). 


\section{Partisan Distribution of Aid, Abuse of State Resources, and Vote Buying}

Popular choice may also have been influenced by vote buying, the partisan distribution of aid, and abuse of state resources. The Presidential Input Scheme was evidently abused by Zanu-PF for vote buying. Significantly, then ZanuPF Member of Parliament and minister, Jonathan Moyo, revealed in a public lecture at SAPES Trust on 1 June 2017 that despite the bad state of the economy, his party was difficult to dislodge "because it was organically linked with the people'. Moyo pointed out that 1.6 million households had been given support through the scheme for the current season in a country where the livelihoods of 1.8 million households in Zimbabwe (nine million people) depended on land. While addressing a campaign rally in Mutoko on 9 June 2018, Zanu-PF presidential candidate, Mnangagwa, made the following comment about the same scheme:

Those we gave farms under the land reform programme can join command agriculture where we give everything, though of course they will pay back. For the rest, 1.8 million families countrywide, we used to give 5.6 million USD each year, we gave 30 million last year. But this coming year it will be 487 million so that people can get free inputs and have enough to feed themselves and sell the surplus to the Grain Marketing Board.

Mnangagwa made copious promises to communities when campaigning. For example, in Mutoko he said that since the area was not conducive for farming but had minerals, 'artisanal miners' as he referred to them (no longer called 'makorokoza's) would be supported. Instead of having to get licences before they could mine, Mnangagwa said that they now had to mine first to be able to raise money for the licences. Regarding the black granite that is abundant in Mutoko, he promised that his government would introduce a law requiring companies to partner with black people and that all communities around a mining area would benefit from the mining. For the past seven years the community had wanted a bridge in the area mended, and he promised to tell Minister Gumbo to do so by Parliament's next meeting.

Masunungure observes that the use of state-financed patronage has been a constant in Zanu-PF's election strategy (2009, p. 68). The CCJP notes that food aid, agricultural inputs, access to land and local resources, and local employment opportunities, livestock and everything else needed for livelihoods have been politicised over the past decade and used to coerce voters to support Zanu-PF (CCJP 2018, p. iv). Yet this use of public resources as a form of patronage to sway

4 A derogatory name referring to illegal miners. 
voters is not an option for opposition parties, especially in rural areas (Sachikonye 2005, p. 70). In the CCJP's observation (2018, p. vi):

Often, the State has ceased to exist beyond the provincial levels. Political party functionaries - some of whom have been recruited within the traditional leadership, civil and security service - take charge of all the State welfare and livelihood support interventions from the province to the village level. As such, some poor and marginalised citizens, who are the majority of voters, have been heavily coerced to give up democracy and political independence to secure their residential places and benefit from welfare and humanitarian aid.

Ahead of the 2018 elections, EOMs noted the abuse of state resources and politicisation of aid (CCJP 2018; ZIEOM 2018, p. 9). The CCJP records most of the cases. Those who were not Zanu-PF members or supporters were explicitly told not to bother attending distribution gatherings as they would not receive anything. In one case, a desperate family pleaded for a chance to rejoin Zanu-PF so that they could benefit (CCJP 2018, p. 10). The CCJP notes many other similar cases where well-known opposition party activists were denied food aid while some families had to switch political parties and liaise with the headmen to receive food relief. In this way Zanu-PF courts voters, particularly in rural areas. The rural voter has received, and will retain, largesse through affiliation to Zanu-PF and as a result is at the mercy of Zanu-PF and may exercise his or her vote accordingly.

\section{Partisan Role of Traditional Leaders}

Against the principle of non-partisanship enshrined in Section 281(2)(a-c) of the Constitution of Zimbabwe, the institution of traditional leadership has been an appendage of Zanu-PF. Traditional leaders played a partisan role in the 2018 harmonised elections (ZESN, 2018c, p. 10; ZEOM 2018, p. 9). The CCJP notes cases of traditional leaders who were coerced into encouraging their villagers to vote for Zanu-PF. Village heads were instructed to threaten villagers with the loss of land if they did not vote for Zanu-PF, and those village heads accused of supporting candidates opposing Zanu-PF were replaced (ibid.).

The abuse of traditional leadership was a well-intended strategy. Addressing a rally in Mutoko on 9 June 2018, Mnangagwa counselled those who hoped to be elected to Parliament:

If you are wise, for those who are campaigning to be MPs, let me tell you a secret. If you go to the Chief in your constituency with a new 
blanket, groceries, and a goat and say to him, Chief I want to work in your area, humbling yourself, clapping your hands in honour. If he receives, then you know $50 \%$ is done because the Chief will call his headmen and sabhuku's and tell them that he has received you and ask them to do the same. That way you will easily find your way to Parliament.

He advised traditional leaders to work with Zanu-PF since their authority was limited to their respective areas and not the whole country, unlike Zanu-PF. Traditional leaders therefore have a critical role to regiment voters in rural areas and they did so for the 2018 harmonised elections. The Election Resource Centre tried in vain to use the courts to compel the president of the Chief's Council to retract statements, implying that traditional leaders have always supported ZanuPF and would do so again in 2018 (Zimbabwe Legal Information Institute). Heal Zimbabwe Trust (2018) notes that traditional leaders served as party agents for Zanu-PF at some polling stations, and at others literally force-marched people to vote. The use of traditional leaders is effective in a closely-knit rural community and Zanu-PF is organised down to the smallest cell grouping. Also, the possible impact of traditional leaders should be properly understood as traditional leadership is the immediate form of government in Zimbabwe's rural areas where more than $68 \%$ of Zimbabweans reside (CCJP 2018, p. 7). Given the power and influence of traditional leaders, the strategy to mobilise through them probably had considerable influence on voters' choices.

\section{Partisan Role of the Military}

According to Masunungure (2009, p. 69), democracy requires that the military and security organs of the State should be non-partisan and not serve the state or political actors, whether as individuals or parties. When the military interfere in elections, the peoples' choice is likely to be adversely affected. Historically, the military has covertly and overtly supported Zanu-PF at different junctures in Zimbabwean elections. Zanu-PF used its military wing, the Zimbabwe African National Liberation Army (ZANLA), in the build-up to the 1980 elections (Sithole \& Makumbe 1997, p. 134). Sachikonye notes that the Joint Operations Command (JOC) comprising commanders of the army, air force, police, intelligence, and prisons became prominent in political and election strategies in the post-2000 era (2009, p. 82). Dabengwa commented on the role of the JOC and the military in elections:

It is obvious that JOC is in control of the country. Nothing can be done without reference to that security system that was created since 
2008. After the results of the 2008 election were cleared, it was JOC which said they were not to be announced over a period of time until they were able to manipulate everything and come up with a result that would keep Zanu-PF government in power. They (JOC) are physically there. They are deployed each time there are elections. Army commissars go around to influence voting in each constituency. Besides that, it is the army, police and other security personnel that actually administer the process of voting.

(Muvundusi 2017)

Endorsing Dabengwa's comments were reports of a sudden increase in army and police presence in Chimanimani West constituency ahead of a by-election held on 26 November 2016 (Zimbabwe Peace Project By-elections Update 2016). Following the determinative role of the military in November 2017, the question of the role the military would play in the 2018 harmonised elections remained fundamental. But the enthusiasm in the country, particularly Harare, because Mugabe was finally going, led many to overlook the implications of the role the military played at a time when the end appeared to justify the means.

There were however reservations regarding the role of the military as well as the so-called 'new dispensation' on free, fair, and credible elections (ZESN, 2018f p. 37). The ZIEOM notes that, while the Zimbabwe Defence Forces (ZDF) stated that it would not interfere in the elections, it did not clearly commit to respecting the outcome regardless of the winner (2018, p. 9). The ZIEOM also notes incidents of military personnel in civilian clothing engaged in politically intimidating activities. A pre-election Afrobarometer survey conducted between June and July 2018 showed that $44 \%$ of Zimbabwe's population believed that the security forces would not accept a ruling party loss (ibid.).

The 2017 military intervention dubbed 'Operation Restore Legacy' arguably confirmed the stakes of the military in party and electoral politics. In a document attached as Annexure 1 to its petition to the AU and the SADC, the New Patriotic Front $(\mathrm{NPF})^{5}$ notes the following as part of the rationale for 'Operation Restore Legacy':

More worrisome were the divisive, manipulative, and vindictive acts by a cabal (the so-called G40 cabal that was characterised as negative, counterrevolutionary elements who had hung around President Mugabe) which threatened the electability of Zanu-PF in

5 The NPF - formed after Mugabe was dethroned - comprised disaffected members of a faction (the so-called G40) that was violently opposed to the so-called 'Team Lacoste' which supported Emmerson Mnangagwa as Mugabe's successor. 
the impending 2018 harmonised elections, thus raising the spectre of an electoral defeat which harkened [sic] to 2008 electoral crises and more broadly, to a similar fate suffered by Zambia NPF.

(NPF Petition to the AU and SADC 2018, p. 8)

The rationale of military intervention as presented by the NPF supports Masunungure's observation (2009, p. 69) that owing to the history of the protracted liberation struggle of the 1970s, there is a symbiosis between the military elite and the political elite mediated by Zanu-PF. He asserts (ibid., p. 70) that:

In the new party-state, many who constitute the military and security elite have found it difficult to dissociate themselves from the party... In this complex scheme of things, when the party is in trouble, it is incumbent on the soldier class to come to the party's aid.

Professor Miles Tendi, who has extensively researched and published on the military in Zimbabwe, states that:

In 2006, I interviewed high-ranking members of the military in Zimbabwe, including Chiwenga. I can authoritatively state that sections of the Zimbabwean military with liberation war experience, which are dominated by generals such as Zvinavashe, Chiwenga and Perence Shiri, have never been professional. They have always had a stake in national politics. They see themselves as 'guardians' of the legacy of Zimbabwe's liberation struggle and of the country's sovereignty. They believe the country's independence and sovereignty are only safe in Zanu-PF's hands.

(The Guardian 19 June 2008)

The involvement of the military in Zanu-PF's campaign for the 2018 elections was later hinted at by some Zanu-PF politicians. Special advisor to Mnangagwa, Christopher Mutsvangwa, was amongst those who led the civilian process of popularising and legitimising the November 2017 military intervention. He allegedly claimed that Zanu-PF would mobilise for and win the 2018 elections working with the Zimbabwe Defence Forces (Mushava 2017). Mutsvangwa later argued that he was misquoted (The Zimbabwe Mail 19 December 2017). But similar remarks were made by others in Zanu-PF. In a statement construed to be a reminder of the role he played in previous elections, Zanu-PF Political Commissar, Retired Lieutenant General Engelbert Rugeje, addressed party supporters in January 2018 as follows: 
We are getting towards important elections this year. I came here in 2008 when things were bad. I don't know where Masvingo had got this spirit and I came and sorted things out. I came back again in 2013 and led the campaign team and I moved around the province addressing rallies and the results were impressive and this saw the current party president [Mnangagwa] giving Masvingo the post of political commissar. I expect you to give ZANU-PF all seats in Masvingo now that I am full time in politics.

(Bishi 2018)

Rugeje's statement betrays the partisan role of the military in elections; though he was still with the military, he intervened to 'sort things out and lead campaign teams', addressing rallies in both the 2008 and 2013 harmonised elections. In 2016, Josiah Hungwe, Minister of State for Masvingo Province, was quoted in The Zimbabwean (5 December 2016):

Yes, we can go to war. We can hire our army .... Our soldiers can come in to help us. We will never allow opposition political parties to rule this country. We are going to have President Mugabe as our candidate in 2018 and his predecessors must have war credentials. Don't forget what Rugeje did in Masvingo in 2008 ... we can call him again in 2018.

In December 2017, Hungwe said that Zanu-PF would campaign side by side with the army as in the Bible kings ruled with the army on their side (Pindula 2017).

An even more threatening statement was made by then Deputy Minister for Finance, Terrence Mukupe. Addressing party supporters at a Zanu-PF cell meeting on 23 May 2018, he said 'It is difficult to imagine that the military forcibly seized power from Mugabe to hand it over to a kid talking about spaghetti roads and impregnating all women' (Ndawana 2018). This implies that the military would not countenance the electoral defeat of Zanu-PF.

The NPF petition (2018, p. 8) claims that over 2000 commissars comprising retired senior officers from the army were embedded in communities across the country before the elections. Closer to the election, the Zimbabwe Democracy Institute (ZDI) published a report corroborating the deployment of the military in communities (ZDI 2018). This was echoed by the opposition MDC Alliance and Joice Mujuru who wrote to Mnangagwa calling for the withdrawal of 3000 soldiers from communities (Mhlanga 2018).

On 1 August, a day after the elections, the military intervened to quell protests by MDC Alliance supporters who accused ZEC of attempting to rig the 
election by colluding with Zanu-PF in delaying the announcement of presidential election results. ${ }^{6}$ The military's use of a disproportionate amount of force and live ammunition resulted in the death of at least seven civilians. The military reportedly imposed unofficial curfews, indiscriminately assaulting people in some high-density suburbs, particularly in Harare. The military involvement in the preelection period and elections administration may have influenced voter choice.

The preponderant role of the military has been the basis of calls for security sector reforms from civil society and opposition political parties in Zimbabwe. But Knox Chitiyo and Steve Kibble (2014, p. 22) note that the military and Zanu$\mathrm{PF}$ made it clear that security-sector reform is not an option. Chitiyo quotes one senior ZNA officer in a confidential interview (ibid.):

Why should we reform? We are a professional organization which has operated in Zimbabwe and in operations across Africa. So what is there to reform? To us security sector reform means regime change, so that is not going to happen [...] If the British want to talk to us, then they must forget about this security sector reform.

With Mnangagwa in power, it is difficult to fathom the possibility of even a modicum of genuine security sector reforms. At a time when he was Defence Minister, Mnangagwa said:

As long as we are here in leadership, we will make sure the Defence Forces of the Republic of Zimbabwe will continue to defend the national interests and to safeguard our values and ideals which our people died for. They want to hear that you are compliant, that you accept security sector reforms.... They would want you to say you are non-political, you must serve any government.

(NewsDay 2013; The Herald 2013)

Yet the continued involvement of the military in elections raises fears that with militarised elections, 'if the ballot produces an outcome that is incongruent with the expectations of the gun wielders, then the bullet will shred the ballot' (Masunungure 2009, p. 84), alleging 'that in the political world of Zanu-PF, the ballot is subservient to the bullet which is supreme'; arguing that this view is the supreme vitiation of elections as an expression of democratic choice (ibid.).

6 Though the Constitution provides for the announcement of election results 'as soon as possible after the close of the polls', ZEC was still within the five-day period provided for in the Electoral Act to declare presidential election results. 


\section{Intimidation}

Intimidation has been a constant tactic in Zanu-PF's electoral campaigns since 1980 (Kriger 2005). EOMs concur that ahead of the 2018 harmonised elections the environment was largely peaceful with minimum levels of overt violence (CCJP 2018, p. 4; ZESN 2018c, p. 42; ZIEOM 2018, p. 9). A peace pledge was signed for the first time, with the coordination of the National Peace and Reconciliation Commission, whereby political parties committed to peaceful campaigns. However, not all conditions for peaceful elections were met. SADC Principles and Guidelines (2015, p. iii) define 'peaceful' to mean:

electoral pro(cesses [that] are punctuated by calm; are undisturbed and untroubled by violence or intimidation; are conflict-free and generally exude an atmosphere where all citizens are free and unhindered to express their right to vote, are able to offer themselves without intimidation for election, communicate freely their electoral choices, and enjoy freedom of assembly and association.

While few cases of overt violence were recorded, covert violence or intimidation was rife. This includes deliberate misinformation that BVR would make it possible to track votes, and threats of retributive violence reminiscent of those which marked the campaign period ahead of the 2008 runoff elections, should Zanu-PF lose the elections (ZESN 2018, p. vi; ZIEOM 2018, p. 9). ZESN notes that BVR-related intimidation, which misled registrants into losing faith in the secrecy of the ballot, was prevalent in most villages and some urban centres. Traditional leaders, ZanuPF district chairpersons, Zanu-PF councillors, members of parliament, and other party officials were implicated (ZESN 2018, p. 38). Voters were also threatened with unspecified retribution in cases of non-compliance while the perpetrators of harassment and intimidation did so with impunity (ibid.).

The CCIP argues that the strategy of intimidation, isolation, and violence has been similar and implemented at almost the same time across the country, pointing to the fact that it was deliberate and well planned. Those structures, institutions, and individuals implicated were rewarded through a well-resourced patronage system (ZESN 2018, p. 4).

On election day in the 2018 elections, named Zanu-PF members threatened voters with violence in the event of a runoff in Mt Darwin Ward 34 (Heal Zimbabwe Trust 2018). Zanu-PF won with 1580 votes followed by the MDC Alliance with 307 votes. The probable impact of intimidation on voter choice should not be underestimated. In a survey conducted by the CCJP ahead of the 2018 elections, more than $95 \%$ of respondents, especially those from peri-urban 
and rural areas, indicated that elections meant fear, violence, coercion and intimidation, especially by traditional leaders and political activists, as well as the burning of houses and killing of political opponents (ibid.). Elections reminded respondents of the violent 2008 elections when they had to vote as instructed. Elections were also associated with internal displacements, especially in the event of a presidential runoff when they might have to desert their homes and become internal refugees after voting for their preferred candidate.

\section{Assisted Voting}

Observers reported high levels of assisted voting nationwide which could have compromised the secrecy of the ballot (IRI/NDI ZIEOM 2018, p. 10). Assisted voting is a concern in Zimbabwe's elections with a history of cases where illiteracy has been feigned, including by teachers, at the behest of Zanu-PF activists who would then become voting assistants. In the harmonised elections, Heal Zimbabwe Trust (2018) reported that a named Zanu-PF supporter assisted several people to vote at Mutauto Secondary School polling station in Buhera Ward 18. At Somthanyelo polling station in Matebeleland North, at least six youths who had completed ' $\mathrm{O}$ ' Level were assisted to vote by the same elderly persons before this was noticed and stopped by the Presiding Officer (CCJP 2018, p. 41). Zanu-PF possibly relied on the same tactic, contrary to the practice stipulated in the ZEC 2018 elections manual that a confidante can assist only one person.

\section{Suspicious Results Management}

Suspicious results management by ZEC diminishes the credibility of the 2018 elections. In terms of Article 4.1.12 of the SADC Principles and Guidelines, member states should ensure that all electoral stakeholders accept the election results to have been free, fair, transparent, credible and peaceful, as proclaimed by competent and independent national electoral authorities in accordance with the respective laws of the land. Because losers may refuse to accept results, efforts must be taken to ensure the incontestability of election results. This can be partly achieved by having EMBs that meet the above criteria.

According to the EU EOM (2018, p. 35), citing the earlier lack of V11 forms, ZEC officers in Makoni North were still completing the forms two days after election day in the absence of polling staff and party agents. Further, ZEC revised the election results and there were mistakes in the final set of results, though these were found to have no material effect on the overall outcome of the election (ZESN 2018c, p. 67). In a PVT it conducted, ZESN found the results announced by the ZEC to be within its projections (ZESN 2018). Without evidence to back 
claims of vote manipulation, the MDC Alliance found it difficult to convince the Constitutional Court to reverse the declaration of Mnangagwa as the victor. However, inconsistences in the results understandably raised fears that the people's free choice may have been disregarded as even the ZESN PVT could not confirm whether or not there had to be a runoff. Both the Commonwealth and European Union recommended transparency and verifiability in the results management process (Commonwealth Observer Group 2018, p. ix).

\section{The Court Case}

Article 5.1.4 of the SADC Principles and Guidelines requires member states to ensure justice in the resolution of disputes arising from elections by means that include constitutional and electoral courts. In 2018 the MDC Alliance filed a petition seeking to overturn the ZEC decision to announce Mnangagwa as the winner of the election on the basis of alleged rigging. The case was dismissed because the complainant could not prove the case beyond doubt, as the fixation on numbers and disregard of other issues pointed to an unfair environment. The judiciary has been identified as one of the key institutions that experienced a devaluation of their powers and autonomy from 2000 to 2008 (Bratton \& Masunungure 2008, p. 46; Sachikonye 2009). Article 4.1.13 of the SADC Principles and Guidelines calls for the condemnation and rejection of non-acceptance of results, after due process, as announced by the legally competent authorities. The key question remains whether the Constitutional Court could be adjudged competent after commenting on the position the opposition continues to hold, ignoring the court judgement and maintaining that Mnangagwa is an illegitimate president without a mandate from the electorate.

\section{Verdict}

John Makumbe (2006, p. 46) asserts that 'in some, if not many, African countries, the ruling party has mastered and perfected the art of manipulating electoral systems with the primary objective of deceiving the people into believing that they govern themselves'. He argues that 'For the most part, the incumbent party elites are able to thwart the people's choice and desperately hold on to political power' (ibid.). The paper argues that when the cumulative effect of the issues discussed above is considered, voters may not have been able to express free choice in Zimbabwe's 2018 elections.

Owing to some of these discussed malpractices, ZESN concludes that 'the integrity of the 2018 harmonised elections was undermined by an uneven playing field' (ZESN 2018c, p. 71). The ZIEOM (2018, p. 6) asserts 
... while some significant incremental improvements were demonstrated in the 2018 elections, Zimbabwe has not yet established a process that treats all political parties equitably and allows citizens to be confident that they can cast their vote and express their political opinion free from fear of retribution.

In short, the 2018 elections in Zimbabwe did not pass the credibility test.

\section{CONCLUSION}

Credible elections should afford voters free choice when they cast their ballot, without manipulation of any kind. While there were notable improvements in Zimbabwe's elections (as discussed in the paper), the 2018 harmonised elections still lacked credibility.

Evidence, particularly in the pre-election and election periods, suggests that some voters may not have been able to exercise free choice through the ballot box. Piecemeal legislative reforms were instituted at the eleventh hour despite Zanu-PF having been initially reluctant, insisting that the situation was fair. But besides legislative issues, the political environment still favoured Zanu-PF with a questionable independence of the ZEC. There was also voter intimidation or covert violence; media bias; the partisan role of traditional leaders; politicisation of benefits, abuse of State resources, and vote buying; and the involvement of the military. The immediate post-election period compounded these suspicions.

While it may not be easy to quantify the cumulative effect of these concerns, there is reason to conclude that they diminished the credibility of the elections. Zimbabwe's electoral laws need comprehensive reform, with improved election administration to ensure a level playing field.

\section{RECOMMENDATIONS}

The study recommends the following:

- Strengthening ZEC's independence and impartiality by freeing it from executive interference, addressing militarisation concerns, and meaningfully engaging stakeholders;

- Ensuring equitable treatment, in terms of timing and prominence of coverage, of all political parties and/or electoral candidates in all print and electronic media;

- Legislating and enforcing laws against partisan aid distribution, abuse of State resources, and vote buying in elections; 
- Enforcing constitutional provisions on non-partisan traditional leaders and establishing an integrity and ethics committee, envisaged under Section 287 of the Constitution, whose responsibilities would include dealing with complaints against traditional leaders;

- Instituting security sector reforms to stop the military from meddling in electoral politics, and setting up an independent complaints mechanism as enshrined in Section 210 of the Constitution to allow for receiving, investigating, and remedying the public's complaints against state security personnel;

- Limiting the use of assisted voting to cases in which it would be absolutely necessary to ensure secrecy of the vote;

- Taking stern punitive measures against perpetrators of electionrelated violence and intimidation;

- Ensuring an unassailable, transparent and verifiable results management process; and

- Strengthening the competency, independence, and impartiality of the courts to ensure justice in the resolution of electoral matters.

\section{Acknowledgements}

The author acknowledges comments and feedback from Professor Lloyd Sachikonye, Professor Roger Southall, and anonymous reviewers.

\section{Disclaimer}

The author has been with the Zimbabwe Election Support Network for the past three years. Views expressed in the article are the author's own and do not reflect the position of ZESN unless citation indicates that to be the case. 


\section{— REFERENCES}

Afolabi, SO 2017, 'Interrogating the Credibility of Elections in Africa: Implications for Democracy, Good Governance and Peace?', Africology: The Journal of Pan African Studies, vol.10, no.1, pp. 3-24.

African Union Election Observation Mission 2018, 'AUEOM to Zimbabwe 30 July Harmonised Elections Preliminary Statement' AUEOM, Harare.

Afrobarometer 2017, 'In Zimbabwe, opposition and uncommitted support grand opposition coalition idea', Dispatch No. 145, 10 May, Harare.

Afrobarometer 2018, 'Findings from a pre-election baseline survey in Zimbabwe: April/May 2018', Harare.

Bishi, M 2018, 'Rugeje threatens a repeat of 2008', The Mirror, January.

Bob-Milliar, GM \& Paller, JW 2018, 'Democratic Ruptures and Electoral Outcomes in Africa: Ghana's 2016 Election', Africa Spectrum, vol 53, no. 1, pp. 5-35.

Bratton, M \& Masunungure, E 2008, 'Zimbabwe's Long Agony', Journal of Democracy, vol. 19, no. 4, pp. 41-55.

Catholic Commission for Justice and Peace (CCJP) 2018, 'CCPJ in Zimbabwe Election Observation Report for 2018 Zimbabwe Harmonised Elections', CCJP, Harare.

Charamba, CF 2016, 'The problem is not electoral laws', The Herald, 14 September. Chidza, R 2018, 'Electoral laws reform remains superficial', NewsDay, 20 April.

Commonwealth Observer Group 2018, Reports of the Commonwealth Observer Group Zimbabwe Harmonised Elections 30 July 2018, The Commonwealth.

Crisis in Zimbabwe Coalition 2018, 'Appointment of Silaigwana a consolidation of the militarisation of ZEC'. http://kubatana.net/2018/03/16/appointmentsilaigwana-consolidation-militarisation-zec/

Cyllah, A (ed.) 2014, 'Elections Worth Dying For? A Selection of Case Studies from Africa', International Foundation for Electoral Systems, May.

DailyNews 2018, 'ZEC boss fired', 28 February.

DailyNews 2018, 'Silaigwana's Appointment as ZEC Chief Elections Officer slammed', 16 March.

da Rocha, JP \& Khuon PR 2018, 'The Africanization of Democracy - Elections and Conflict Prevention in Sub-Saharan Africa', Sociology and Anthropology vol. 6, no.1, pp 152-175.

Heal Zimbabwe Trust, Zimbabwe 2018, Harmonised Elections - End of Day Update, 30 July, http://kubatana.net/2018/07/30/zimbabwe-2018-harmonised-electionsend-day-update/

International Republican Institute/National Democracy Institute Zimbabwe International Election Observation Mission (IRI/NDI ZIEOM) 2018, 'IRI/NDI ZIEOM Final Report', IRI/NDI ZIEOM, Harare. 
Kriger, N 2005, 'ZANU-PF Strategies in General Elections, 1980-2000: Discourse and Coercion', African Affairs, vol. 104, no. 414.

Makumbe, J 2006, 'Electoral Politics in Zimbabwe: Authoritarianism Versus the People', Africa Development vol. XXXI, no. 3, pp. 45-61.

Makumbe, J 2009, 'Theft by Numbers', in EV Masunungure (ed), Defying the Winds of Change: Zimbabwe's 2008 Harmonised Elections, Weaver Press, Harare.

Manaiti, O 2018, 'Mujuru stoned at rally', NewsDay, 2 February.

Maodza, T 2018, 'Let them march, says President ... The playing field is perfectly level', The Herald, 6 June.

Mapuva, J 2013, 'Elections and electoral processes in Africa: A gimmick or a curse?' African Journal of History and Culture, vol. 5, no. 5, pp. 87-95

Masunungure, EV (ed) 2009, Defying the Winds of Change: Zimbabwe's 2008 Harmonised Elections, Weaver Press, Harare.

Media Monitors 2018, 'Media and Elections', in ZESN Report on the 30 July 2018 Harmonised Elections, ZESN, Harare.

Mhlanga, B 2017, 'Mnangagwa, military elections role exposed', NewsDay, 28 April. Mhlanga, B 2017, 'Opposition parties rekindle push for electoral reforms', DailyNews, 22 May.

Mhlanga, B 2018, 'Mujuru takes on Mnangagwa', NewsDay, 26 February.

Mhlanga, B 2018, 'Soldiers make up 15\% of ZEC's staff', NewsDay, 27 February.

Moyo, J 2017, 'Whither Zimbabwe's Nationalist Project?', 3 June, https://www.youtube. com/watch?v=TqEEgWNvltg

Mungwari, T \& Vhutuza, E 2017, 'Opposition political parties' coalition in Zimbabwe: Challenges and possibilities', African Journal of Political Science and International Relations vol. 11, no. 7, pp. 172-181.

Mushava, E 2017, 'Army will play role in 2018 polls: Mutsvangwa', NewsDay 16 December.

Muvundusi, J 2017, 'JOC running Zim elections: Dabengwa', Southern News, 26 July. Ndawana, C 2019, 'Mukupe offside on military intervention if Chamisa wins', NewsDay, 29 May.

New Patriotic Front 2018, Petition to the African Union and Southern African Development Community. Available at $<$ https://t792ae.c2.acecdn.net/wpcontent/uploads/2018/02/New-Patriotic-Front-NPF-Documents-To-AfricanUnion.pdf $>$. [16 September 2019].

NewsDay 2013, 'Mnangagwa confuses national security', 8 February.

NewsDay 2018, 'Minister says no electoral reforms needed', 5 January.

Newsday 2018, 'Soldiers make up 15\% of ZEC staff', 27 February.

Pindula 2017, 'ZANU-PF will use soldiers in 2018 election campaign', Bulawayo24 News, 13 December. 
Sachikonye, LM 2005, 'Political Parties and the 2005 Elections in Zimbabwe', Journal of African Elections, vol. 4, no. 2, pp 63-73.

Sachikonye, L 2009, Between Authoritarianism and Democratization: The Challenges of a Transition Process in Zimbabwe, Institute for Development Studies, University of Zimbabwe, Harare.

Sithole, M \& Makumbe, J 1997, ‘Elections in Zimbabwe: ZANU-(PF) Hegemony and its Incipient Decline', African Association of Political Science vol. 2, no. 1, pp. 122-139.

Soler-Crespo, D 2019, The Slow Death of Liberation Movements in Southern Africa, Navarra Center for International Development, Pamplona, Spain.

Southern African Development Cooperation Parliamentary Forum Election Observation Mission 2018, 'Preliminary Mission Statement by the SADC PF EOM to the 2018 Zimbabwe Harmonised Elections', SADC PF.

Southern African Political Economy Series and National Endowment for Democracy 2017, Zimbabwe in Transition: Reform and Reconstruction Conference, 29-30 June, Harare.

SADC Principles and Guidelines 2015, (rev.), Southern African Development Community, Pretoria.

Sweeney, WR 2014, 'Foreword', in Cyllah, A (ed) 2014, Elections Worth Dying For? A Selection of Case Studies from Africa, International Foundation for Electoral Systems.

Tendi, BM 2008, 'After Mugabe Who?', The Guardian, 19 June.

The Herald 2013, 'No security sector reforms: Mnangagwa', 4 February.

The Standard 2016, 24 January.

The Sunday Mail 2017, 'ZEC ready for general elections', 9 July.

The Zimbabwe Mail 2017, 'Mutsvangwa denies claims he said army will campaign for ZANU-PF', 19 December.

The Zimbabwean 2016, 'ZANU-PF will unleash army to defend Mugabe rule', 5 December.

Tshili, N 2016, 'ZANU-PF will never reform itself out of power, Prof Moyo declares', The Chronicle, 6 September.

United Nations Economic Commission for Africa 2013, African Governance Report III, Elections \& the Management of Diversity, UNECA/Oxford University Press, Addis Ababa.

Zimbabwe Democracy Institute 2018, 'ZANU-PF/Military Deterrence of the Village Vote', ZDI, Harare.

Zimbabwe Election Support Network 2015, 'ZESN Report on the Epworth, Marondera Central and Mbire 19 September 2015 National Assembly By-elections', ZESN, Harare. 
Zimbabwe Election Support Network 2017, 'Chiwundura National Assembly Byelection', ZESN, Harare, 2017.

Zimbabwe Election Support Network 2018, 'ZESN Final Voters' Roll Audit Report', ZESN, Harare.

Zimbabwe Election Support Network 2018a, 'ZESN Report on Pre-election Political Environment and Observation of Key Electoral Processes', ZESN, Harare.

Zimbabwe Election Support Network 2018b, 'Biometric Voter Registration Observation Report', ZESN, Harare.

Zimbabwe Election Support Network 2018c, 'ZESN Report on the 30 July 2018 Harmonised Elections', ZESN, Harare.

Zimbabwe Election Support Network 2018d, 'Issue Two - ZESN Long Term Observation Report on the Pre-election Political Environment and Observation of Key Electoral Processes 25 July 2018', ZESN, Harare.

Zimbabwe Election Support Network 2018e, 'Issue 3 Pre-election Long Term Observer (LTO) Update 29 July 2018', ZESN, Harare.

Zimbabwe Legal Information Institute, ERC and Chief Fortune Charumbira and National Council of Chiefs versus Minister Of Local Government, Public Works And National Housing https://zimlii.org/zw/judgment/harare-high-court/2018/270

Zimbabwe Peace Project 2016, 'Chimanimani West pre-election environment vile', 22 November 2016, https://www.zimpeaceproject.com/blogs-vlogs/byelection-updates/

Zulu, B 2015, 'Zimbabwe Opposition Parties Sign Document Demanding Electoral Reforms', Voice of America, 2 December. Available at $<$ https://www. voazimbabwe.com/a/zimbabwe-politics/3084529.html>. [13 December 2019]. 